Published in final edited form as:

JMed Chem. 2016 February 11; 59(3): 1102-1115. doi:10.1021/acs.jmedchem.5b01696.

\title{
The Effect of Small Molecules on Sterol Homeostasis: Measuring 7-Dehydrocholesterol in Dhcr7-Deficient Neuro2a Cells and Human Fibroblasts
}

\author{
Zeljka Korade ${ }^{\dagger, \ddagger, \#}$, Hye-Young H. Kim ${ }^{\S, \#, ~ K e r i ~ A . ~ T a l l m a n}{ }^{\S}$, Wei Liu§, Katalin Koczok $\|$, \\ Istvan Balogh || , Libin Xu§, ${ }^{\S}$, Karoly Mirnics ${ }^{\dagger, \ddagger}$, and Ned A. Porter ${ }^{\star}, \dagger, \S$ \\ †Vanderbilt Kennedy Center for Research on Human Development, Vanderbilt University, \\ Nashville, Tennessee 37235, United States \\ ‡Department of Psychiatry, Vanderbilt University, Nashville, Tennessee 37235, United States \\ $\S$ Department of Chemistry and Vanderbilt Institute of Chemical Biology, Vanderbilt University, \\ Nashville, Tennessee 37235, United States \\ $\|$ Department of Laboratory Medicine, Division of Clinical Genetics, University of Debrecen, \\ Nagyerdei krt. 98, 4032 Debrecen, Hungary
}

\section{Abstract}

\begin{abstract}
Well-established cell culture models were combined with new analytical methods to assess the effects of small molecules on the cholesterol biosynthesis pathway. The analytical protocol, which is based on sterol derivation with the dienolphile PTAD, was found to be reliable for the analysis of 7-DHC and desmosterol. The PTAD method was applied to the screening of a small library of pharmacologically active substances, and the effect of compounds on the cholesterol pathway was determined. Of some 727 compounds, over 30 compounds decreased 7-DHC in Dhcr7-deficient Neuro2a cells. The examination of chemical structures of active molecules in the screen grouped the compounds into distinct categories. In addition to statins, our screen found that SERMs, antifungals, and several antipsychotic medications reduced levels of 7-DHC. The activities of selected compounds were verified in human fibroblasts derived from Smith-Lemli-Opitz syndrome (SLOS) patients and linked to specific transformations in the cholesterol biosynthesis pathway.
\end{abstract}

\section{Graphical Abstract}

\footnotetext{
*Corresponding Author, Phone: 615-343-2693. Fax: 615-343-5478. n.porter@ vanderbilt.edu.

${ }_{+}^{\perp}$ Present Address, For L.X.: Department of Medicinal Chemistry, University of Washington, Seattle, WA 98195, United States. \#Z.K. and H.-Y.H.K. contributed equally to this publication

ASSOCIATED CONTENT

Supporting Information

The Supporting Information is available free of charge on the ACS Publications website at DOI: 10.1021/acs.jmed-chem.5b01696. Synthesis of standards, sterol profiles, and cell viability for selected compounds in Dhcr7-deficient Neuro2a cells, verification of screening hits in SLOS human fibroblasts (PDF)

The authors declare no competing financial interest.
} 

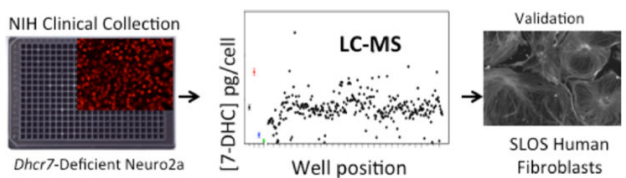

$5 \%$ of the

Collection

$\rightarrow$ Decreases

cellular

Dhcr7-Deficient Neuro2a

Well position

Fibroblasts

7-DHC

\section{INTRODUCTION}

The biosynthesis of cholesterol is a complex process that involves multiple enzymes and intermediates. ${ }^{1}$ The pathway from lanosterol to cholesterol includes over a dozen metabolic intermediates, many of which play important roles in cellular processes such as hedgehog signal transduction. ${ }^{2-4}$ Cholesterol is of critical importance in myelination, and normal brain cholesterogenesis is absolutely essential for normal embryonic and perinatal development. Genetic errors affecting transformations that are early in the biosynthesis pathway are generally lethal at preimplantation or the very early embryonic stage, while individuals with inborn errors affecting the last steps of cholesterol biosynthesis can survive to birth, usually with severe consequences. ${ }^{5-16}$

Figure 1 shows structures of three late-stage sterols in the postlanosterol pathway. 7Dehydrocholesterol (7-DHC) and desmosterol are the immediate biosynthetic precursors of cholesterol, and there are known human disorders associated with errors in the conversion of these sterols to cholesterol. ${ }^{5,6}$ 7-DHC accumulates in patients with Smith-Lemli-Opitz syndrome (SLOS), ${ }^{7}$ a metabolic disorder resulting from mutations in the gene encoding 7 dehydrocholesterol reductase ( $D H C R 7$ ), the enzyme that catalyzes the reduction of 7-DHC to cholesterol. ${ }^{8,9}$

The pathophysiology of SLOS is the apparent result of changing the cholesterol/7-DHC balance in these individuals. The physiological concentration of 7-DHC in healthy human plasma is very low $(0.005$ to $0.05 \mathrm{mg} / \mathrm{dL})$, while in persons with SLOS, it is greatly elevated (typically $10 \mathrm{mg} / \mathrm{dL}$ or greater) and cholesterol levels are typically reduced substantially. Cholesterol supplementation is a standard clinical treatment for patients with SLOS, but in practice, this treatment shows only limited efficacy in improving the behavioral phenotype: cholesterol from the systemic circulation does not penetrate the blood-brain barrier, thus limiting the beneficial effects on the brain.

Statins were also a logical, pathophysiology-based therapy for patients with SLOS, alone, or in combination with cholesterol supplementation. ${ }^{17-19}$ Unfortunately, in clinical practice, the benefit for the patients is questionable and several studies did not confirm the previously reported positive effect of simvastatin treatment on anthropometric measures or behavior of patients. The biosynthetic pathway between HMG-CoA reductase and DHCR7 is long and complex, with various intercalated metabolic pathways, and inhibition of HMG-CoA reductase nonselectively represses the whole cholesterol biosynthesis machinery, potentially further reducing the already diminished cholesterol in SLOS patients.

Recent evidence supports the notion that the lack of cholesterol is only partly responsible for the SLOS pathophysiology and pathology. 7-DHC is one of the most reactive lipids known toward free radical peroxidation, its rate constant for propagation being 200 times that of 
cholesterol and 12 times greater than arachidonic acid, a lipid generally thought to be highly reactive. ${ }^{20}$ The accumulating 7-DHC is a highly reactive lipid molecule, and it undergoes spontaneous free radical peroxidation, producing over a dozen oxidation products (i.e., oxysterols) in vitro and in vivo. These 7-DHC-derived oxysterols exert cytotoxicity, reduce cell proliferation, and induce premature cell differentiation and lead to a host of gene expression changes. ${ }^{21,22}$ At nanomolar concentrations in brain tissues of a Dhcr7-KO mouse, 7-DHC oxysterols are strongly neurotoxic. Indeed, oxysterols found in concentrations as high as $3 \mu \mathrm{M}$ in the $\mathrm{KO}$ mouse brain dramatically accelerate differentiation and neurite outgrowth in neocortical neuronal cultures. ${ }^{22}$ The accumulation of 7-DHC leads to a brain region-specific formation of 7-DHC-derived oxysterols that affect expression of many transcripts, ${ }^{23,24}$ leading to premature neuronal differentiation, most likely due to oxysterol formation in the brain tissue.

In summary, recent studies reveal that the accumulation of 7-DHC and its related oxysterols might significantly contribute to the pathogenesis of SLOS, which points to a new direction of therapeutic approach, inhibition of the formation and accumulation of 7-DHC and restoring the 7-DHC/cholesterol ratio.

Desmosterolosis, an autosomal recessive disorder, is even rarer than SLOS. ${ }^{11}$ The mutation in this syndrome is in the gene encoding DHCR24, the enzyme that converts desmosterol to cholesterol. Desmosterol accumulates in these patients and the diagnostic assessment of this syndrome and of SLOS is by analysis of the blood sterol profile. ${ }^{12-16}$ Blood and skin cell sterol profile testing is also used for the diagnosis of the Antley-Bixler, SC4MOL, CDPX2/ Conradi Hunermann, and lathosterolosis disorders, each of which results from defective enzymes promoting a step in the biosynthetic pathway upstream from DHCR24 and DHCR7. ${ }^{11}$

\section{STEROL HOMEOSTASIS AND SMALL MOLECULES}

Recent reports have noted that some prescribed pharmaceuticals have a marked effect on sterol profiles, in some cases leading to plasma levels of 7-DHC in individuals that are as high as those found in some SLOS patients. One recent study examined the medical records of patients with elevated levels of 7-DHC in the absence of a DHCR7 mutation and found a number of individuals who were SLOS false positives and who also had reported a history of treatments with aripiprazole, an atypical antipsychotic, and trazodone, an antidepressant. ${ }^{25,26}$ Other small molecules have been found to perturb sterol profiles in cell culture, and some of these compounds are also prescribed antipsychotic agents. ${ }^{3,27-30}$ AY9944, a small molecule synthesized as a potential cholesterol-lowering agent was found to increase 7-DHC and reduce cholesterol levels in rodents. ${ }^{31-40}$

What seems clear is that exposure to small molecules, some of which are a part of the U.S. Pharmacopeia, can have a profound effect on sterol profiles in vivo. Consideration of these previous studies also suggests that a screening method to identify compounds that affect sterol homeostasis might find general use. ${ }^{41,42}$ We report here the results of a preliminary screen of the compounds in the NIH Clinical Collection, a small library of pharmacologically active molecules. The primary screening method relies on a liquid 
chromatography mass spectrometry (LC-MS) analysis of late-stage cholesterol biosynthetic intermediates including 7-DHC, desmosterol, 7-dehydrodesmosterol (7-DHD), and lanosterol. Dhcr7-deficient Neuro2a cells prove to be particularly convenient for the screen in a 384-well format. The LC-MS sterol analysis in combination with these cells distinguishes not only small molecules that increase levels of 7-DHC but also those that lower levels of this potentially toxic cholesterol precursor. The activities of selected compounds were tested in SLOS human fibroblasts to determine the utility of the approach in identifying compounds that may prove beneficial and/or test the potential toxic side effect of drugs that may be in therapeutic use in SLOS patients.

\section{RESULTS}

We selected Neuro2a and Dhcr7-deficient Neuro2a for the high-throughput screening. Neuro2a cells, a mouse neuro-blastoma cell line, are widely used in the neuroscience community as models of neuronal cell culture..$^{21,23,42-46}$ These cells express all of the enzymes in the cholesterol biosynthesis pathway, and they survive in a lipid-free medium by endogenous biosynthesis. To better understand the molecular consequences of DHCR7 deficiency in neuronal cells, we generated Dhcr7-deficient Neuro2a cells using an shRNA approach. ${ }^{42}$ Dhcr7-deficient cells have downregulated lipid and other transcripts (molecules that play critical roles in proliferation and differentiation, intracellular signaling, vesicular transport, or are inserted into membrane rafts), and they have greatly increased 7-DHC and the 7-DHC derived oxysterol DHCEO. ${ }^{23,41}$ Both control and Dhcr7-deficient cells are sensitive to compounds that affect either Dhcr 7 or Dhcr 24 expression levels. These cells have several benefits as the basis for a small-molecule screening program. The advantages also include fast proliferation as their doubling time is about $20 \mathrm{~h}$. They grow well under a variety of cell culture conditions, including with serum-deficient and lipid-deficient media. Although we used both cell types in the screening procedure, Dhcr7-deficient cells were the better choice to monitor decreases of 7-DHC levels because control Neuro2a cells have very low levels of 7-DHC compared to Dhcr7-deficient cells. ${ }^{47}$

\section{Sterol Assay}

The LC-MS analysis relies on a derivatization strategy that makes use of the reactive compound 4-phenyl-1,2,4-triazoline-3,5-dione (PTAD, see Figure 2). ${ }^{47}$ This dienophile reacts with 7-DHC in a Diels-Alder cycloaddition and in the process introduces five heteroatoms into the adduct structure, 7-DHC-PTAD, ${ }^{48-50}$ improving the MS detection sensitivity for the sterol (Figure 2). ${ }^{51,52}$ The workup for cultured cells involves lysis in methanol, agitation with a PTAD/methanol solution for $20 \mathrm{~min}$ at RT, followed by isocratic UPLC-MS on C18 with methanol mobile phase. A typical UPLC-MS run of Dhcr7-deficient Neuro2a cells in culture is shown in Figure 3. Under our current conditions, 50-60 samples/h can be processed from a multiwell culture plate. A deuterated 7-DHC standard ( $d_{7}$-7-DHC) was synthesized, permitting a quantitative assay with limits of detection of 7DHC-PTAD less than 0.1 picograms; see peaks eluting at $0.81 \mathrm{~min}$ in Figure 3.

Desmosterol, lanosterol, and other sterols having a double bond at C24-25 undergo reaction with PTAD by the "ene" reaction as shown in Figure 2, and these "ene" type products are 
monitored in the UPLC-MS. ${ }^{53-57}$ Isotopically labeled standards for desmosterol ( $\left.0.53 \mathrm{~min}\right)$ and lanosterol ( $0.57 \mathrm{~min}$ ) containing ${ }^{13} \mathrm{C}$ carbons at $\mathrm{C} 24, \mathrm{C} 25$, and $\mathrm{C} 26$ were prepared and can be used for analysis of these sterols; see Figure 3. We conclude further that UPLC separations and mass differences of the PTAD adducts permit quantitative assays of the sterols mentioned above. Lanosterol-PTAD/MeOH, for example, can be readily distinguished from other PTAD products by its mass.

Critical to the expansion of the assay to other sterols is the availability of isotopically labeled standards to be added to cells, tissues, or fluids before workup. The standard must be present in the sample before the PTAD procedure is initiated so that standard and analyte undergo the same derivatizations.

\section{Screens of Presumed "Active" Compounds}

Our first studies were carried out in control Neuro2a cells in 96-well plates. To determine the utility of the PTAD assay in cultured cells, we measured 7-DHC in a specified number of both control and Dhcr7-deficient Neuro2a cells in 96-well plates. We found that 7-DHC could be reliably measured in about 100 Dhcr7-deficient cells while 2000 control Neuro2a cells were required to reach acceptable signal-to-noise levels. ${ }^{47}$ To establish the screening method, we used control Neuro2a and a set of compounds that included antipyschotics and antidepressants that are suspected of increasing levels of 7-DHC in humans. ${ }^{25,26,58,59} \mathrm{We}$ also included in these studies AY9944, the small molecule that is the basis of the SLOS pharmacological rodent model. ${ }^{31-40}$ AY9944, aripiprazole, trazodone, and haloperidol caused elevated levels of 7-DHC in control Neuro2a, results that are consistent with clinical findings. At $100 \mathrm{nM}$, aripiprazole, the top selling drug in 2013, ${ }^{60}$ caused an increase in $7-$ DHC levels in control Neuro2a by over 40 -fold, from 0.08 to $3.2 \mathrm{ng} / \mu \mathrm{g}$ protein, Figure 4 . An effect was also observed of these common pharmaceuticals on levels of desmosterol and lanosterol in these experiments. Compounds that increase 7DHC tended to lower levels of desmosterol and lanosterol (data not shown). The 7-DHC $z^{\prime}$ value ${ }^{61}$ determined for $100 \mathrm{nM}$ aripiprazole vs DMSO treatment in control Neuro2a cells ranged from 0.2 to 0.7 , an acceptable level for a screen but one suggesting that follow-up validation of "hits" should be carried out.

Drugs that lower 7-DHC levels were also detected in this assay, but screening libraries of small molecules with Dhcr7-deficient Neuro2a cells proved more useful for finding compounds that reduce levels of the 7-DHC and as a consequence, its toxic oxysterol derivatives. These experiments have the advantage that 7-DHC levels in the deficient cells $(33 \mathrm{ng} / \mathrm{\mu g} \text { protein })^{47}$ are about 150 times higher than in control Neuro2a cells and compounds that produce lower levels of 7-DHC are readily identified in incubations of the deficient cells.

\section{Screening the NIH Clinical Collection and Dhcr7-Deficient Cells}

About 13000 Dhcr7-deficient Neuro2a cells were added to each well of a 384 plate with the "test compound" concentration in the well set at $1 \mu \mathrm{M}$. In addition to test compounds, each plate had 30 control wells (DMSO only) and additional wells with three drugs (aripiprazole, bazedoxifene, and clomiphene) that were shown to have an effect on 7-DHC in preliminary 
incubations. These compounds were included in the 384-well screen to test the reproducibility of the assay (five wells each at 20 and $200 \mathrm{nM}$ ). The plates were then incubated for $24 \mathrm{~h}\left(37^{\circ} \mathrm{C}\right)$, at which time a nuclear stain (Hoechst) was added and the cells were imaged by automated microscope imager.

Subsequent to the removal of media, cells were lysed in methanol that contained isotopically labeled standards and the cell lysate was transferred robotically to another plate that had the PTAD reagent predeposited. The plate was immediately sealed, then agitated for $20 \mathrm{~min}$ at room temperature, at which time it was ready for MS analysis. The MS UPLC injector acquired samples automatically from the 384-well plate and the chromatography solvent was straight methanol (with no solvent programming) that allowed analysis of 50-60 samples/h. We report here only data for 7-DHC. Follow-up screens carried out in a 96-well format included acquisition of data for 7-DHC, lanosterol, and desmosterol as a function of small molecule treatment.

The output of the screen for a given test compound was the PTAD value in picograms measured in a well divided by cells counted per well. Figure 5 shows output for 7-DHC in a screening of some $40 \%$ of the compounds in the NIH Clinical Collection on one 384-well plate. Note that of the 727 compounds tested, most of them have no significant effect on 7DHC levels in Dhcr 7-def cells (Figure 5), but 33 compounds on the plate gave increases in 7-DHC outside of $3 \sigma$ of the DMSO controls. Another 40 compounds assayed on the plate decreased 7-DHC levels in the cells by the same $3 \sigma$ criterion.

The effect of the test compound aripiprazole on 7-DHC levels in Dhcr7-def Neuro2a was readily detected, $200 \mathrm{nM}$ of the compound doubled the level of 7-DHC in the cells. As shown in Figure 5, bazedoxifene and clomiphene reduced 7-DHC with statistical significance at $200 \mathrm{nM}$ and clomiphene's effect was observed at $20 \mathrm{nM}$ (data not shown).

\section{Validation of HTS Hit Compounds}

We carried out follow-up assays on the compounds from the NIH Collection that decreased 7-DHC levels in Dhcr7-deficient cells in these cells and in human skin fibroblasts from SLOS affected individuals. We also examined compounds that are structurally or therapeutically related to the "actives" in the NIH Collection. These follow-up experiments were carried out in triplicate and included quantitative analysis of 7-DHC, desmosterol, lanosterol, and cholesterol, which was included in the assay described in Figure 3 by extending the UPLC run to $1.2 \mathrm{~min}$ with a flow rate of $550 \mu \mathrm{L} / \mathrm{min}$ and including $d_{7^{-}}$ cholesterol in the workup. Under the conditions of this assay, cholesterol elutes at $0.93 \mathrm{~min}$. GC-MS was also used in these follow-up experiments to include zymosterol (Zym), zymostenol (Zym-e), lathosterol (Lath), 7-dehydrodesmosterol (DHD), 4,4dimethylzymostenol, 24-dihydrolanosterol (diHLan), 7-DHC, desmosterol (Des), and cholesterol (Chol) in the analysis.

Figure 6 shows the postlanosterol sterol profiles determined by a combination of LC-MS and GC-MS methods for three compounds that reduce levels of 7-DHC in Dhcr7-deficient Neuro2a cells. The compounds shown are representative of subsets of compounds, see below, that lead to similar sterol profiles based upon their effect on specific steps in the 
cholesterol biosynthesis pathway. Structures and names of compounds that showed a reproducible effect on the level of one of the cholesterol precursor sterols in Dhcr7-deficient Neuro2a cells or in human fibroblasts are presented in Table 1. Of the compounds in Table 1 that decrease levels of 7-DHC, there are subsets of compounds that have similar structures or are prescribed for similar purposes (Table 2). Compounds affecting 7-DHC are statins (row 1, A-E), selective estrogen receptor modulators (row 1E and 2A-F), antipyschotics (row 3 A-F), antimycotic/-antibacterial/antimalarial drugs (row 4A-F), and steroids (row 6C-F). Thus, the statins, estrogen receptor modulators (SERMs), and antifungals were found to decrease levels of 7-DHC, providing a structure-activity validation of the general screening approach. Statins affect cholesterol biosynthesis at HMG CoA-reductase, a stage in biosynthesis before isoprenoid formation occurs, with the consequence that all sterol levels are reduced, from lanosterol to cholesterol. Because of their well characterized function, we independently verified in our system only two compounds from this group: lovastatin and pitavastatin. There have been reports in the literature that artemisin derivatives like those shown in row 6, A and B, also affect cholesterol biosynthesis at the HMG CoA-reductase step, in this case by down-regulation of the corresponding gene. ${ }^{62}$ SERMs decrease 7-DHC and alter levels of other cholesterol intermediates. The initial HTS screen identified four SERMs that decrease 7-DHC in Dhcr7-deficient cells, consistent with literature reports. ${ }^{29,30,63-65}$ In addition to the four (clomiphene, toremifene, tamoxifen, raloxifene), we obtained several other commercially available SERMs (bazedoxifene, levormeloxifene, and lasofoxifene) along with the selective estrogen receptor downregulator fulvestrant and compared their effects on cholesterol biosynthesis in control and Dhcr7-deficient Neuro2a cells in an independent set of experiments that utilized both the PTAD method and GC-MS analysis. All of the SERMs studied were effective at decreasing 7-DHC in both control and Dhcr7-deficient Neuro2a cells. Assays for other postlanosterol sterols in these experiments showed that biosynthetic steps other than $D h c r 7$ were affected by the compounds, consequently reducing 7-DHC levels in the cells. Tamoxifen, clomiphene, and toremifene appear to have their major effect on the $\Delta 8-7$ isomerase with increased levels of zymostenol and zymosterol being observed while 7-DHC and cholesterol levels are reduced. Raloxifene and lasofoxifene effect both the $\Delta 8-7$ isomerase and the C-24 reductase with increased levels of zymosterol and desmosterol found in the $1 \mu \mathrm{M}$ treatment. Levormeloxifene appears to be one of the more potent compounds, exerting its affect solely on Dhcr24 with the consequent increase of desmosterol and 7-dehydrodesmosterol in the cells.

Clomiphene is marketed as a mixture of geometric stereoisomers, and we observed that both isomers were active, the separated $Z$ and $E$ compounds showing somewhat greater efficacy than the mixture of the two. We note that toremifene and tamoxifen are also obtained as stereoisomeric mixtures, and our studies were carried out on the isomeric mixtures. It seems likely that the effect of concentration on various steps on cholesterol biosynthesis will be variable for the different compounds studied, including steroisomeric mixtures and, as a result, the distribution of sterols will depend both on the particular SERM studied and its concentration. 


\section{Psychiatric Medications Alter Cholesterol Biosyn-thesis ${ }^{25}$}

Several compounds found to significantly decrease 7-DHC in the screen (row 3A-F) are also prescribed as antipsychotics and antidepressants. Thus, 3A-D in Table 1 reduce 7-DHC levels and all are typical antidepressants having common structural features. Complete sterol analysis of these compounds found them to act in a way that parallels the action of the SERMs, ${ }^{63}$ increasing levels of zymosterol and zymostenol. Selected sterol analysis data is presented for these compounds in Supporting Information. Another set of antipsychotics/ antidepressants, including aripiprazole, trazodone, and haloperidol, were among the compounds that increase 7-DHC levels in the 384-well assay shown in Figure 5. It is noteworthy that all of these compounds are used in the treatment of depression, bipolar disorder, and schizophrenia. Indeed, of the compounds in our primary screen of the NIH Clinical Collection in Dhcr7-deficient Neuro2a cells that were shown to affect cholesterol biosynthesis in one way or another, over $20 \%$ are medications prescribed for bipolar disorder, depression, and the like.

\section{Compounds with Antimycotic/Antibacterial/Antimalarial Properties Decrease 7-DHC}

Compounds in this category have well-described pharmacological properties. Several of them act as 14-a demethylase inhibitor (Figure 9), a step in postsqualene cholesterol biosynthesis. Chloroxine and hexachlorophene decrease 7DHC and desmosterol and increase lanosterol and cholesterol. Chloroxine has bacteriostatic, fungistatic, and antiprotozoan properties. Hexachlorophene has been used in soaps and toothpaste and also as a fungicide, plant bactericide, and acaricide. Both compounds at $500 \mathrm{nM}$ greatly decrease cell proliferation of Dhcr7-deficient Neuro2a cells (Supporting Information).

\section{Steroids and Other Active Compounds}

While progesterone's action on DHCR24 is well documented ${ }^{66}$ several compounds identified in this screen have, to our knowledge, not been previously associated with an effect on cholesterol biosynthesis. These include trimebutine, homoharringtonine, and imatinib. Trimebutine, an antimuscarinic and $\mu$ opioid agonist with spasmolytic effects, decreased 7-DHC, and increased desmosterol and lanosterol with no change in cholesterol in our cell culture at $100 \mathrm{nM}$. Imatinib and homoharringtonine are protein tyrosine kinase inhibitors used for the treatment of chronic myeloid leukemia. Homoharringtonine is relatively toxic in our cultures, stopping proliferation of Dhcr7-deficient cells at $10 \mathrm{nM}$ and at higher concentration, leading to cell death (Supporting Information).

\section{Validation of HTS Hits in SLOS Human Fibroblasts}

While Dhcr7-deficient Neuro2a are convenient for use in the HTS screening process, we examined the "hit" compounds in human SLOS fibroblasts to validate the biological response in a different and more relevant cell type. Considering the biological diversity and complexities associated with the use of human derived cells, we examined the effect of "active" small molecules in several different SLOS fibroblasts.

In fibroblasts from SLOS patients, we found that $10 \mathrm{nM}$ of clomiphene, tamoxifen, raloxifene, fulvestrant, levormeloxifene, and bazedoxifene resulted in a statistically significant reduction of 7-DHC without a measurable decrease in cholesterol levels in the 
cells. Toremifene was somewhat less effective, with $100 \mathrm{nM}$ of this compound required to cause a significant reduction of 7-DHC in SLOS HF. The results from this study are presented in Figure 7. Complete data sets for the analysis of SLOS HF and control and Dhcr7-deficient cells treated with SERMs is also presented in Supporting Information. Figure 8 shows compounds that consistently decreased 7-DHC in all SLOS fibroblasts. Because different SLOS HF have different 7-DHC levels, the numbers shown are expressed as a percentage of 7-DHC present in the cells grown in the absence of compounds. The verified hits in SLOS HF suggest that exploring the utility of these compounds may be worthwhile in efforts to normalize lipid metabolism in these cells.

\section{Screening Control Neuro2a Cells}

As noted, one limitation of the use of Dhcr7-deficient Neuro2a cells is that they are less sensitive to small molecules that increase 7-DHC than are control Neuro2a cells (because they already have 7-DHC levels 150 times more than control cells). Thus, while $200 \mathrm{nM}$ aripiprazole results in doubling 7-DHC levels in Dhcr7-deficient Neuro2a, at the same concentration the compound increases 7-DHC in control Neuro2a by a factor of over 40 . Control Neuro2a were also found to be more sensitive than the Dhcr7-deficient cells to trazadone, haloperidol, and AY9944 although these compounds were identified as "actives" in the deficient cell screen. A screen of the entire NIH Collection in control Neuro2a cells is ongoing, and the results of that effort will be reported in due course.

\section{DISCUSSION}

Our screens of Dhcr7-deficient Neuro2a cells show that dozens of compounds of clinical importance can affect one of the steps in postlanosterol cholesterol biosynthesis (Figure 9) and calls attention to the fact that pharmacological intervention can be used to reproduce or in theory to counteract disorders involving disruption of sterol biosynthesis. These disorders are rare, but the consequences of mutations in the enzymes in the cholesterol biosynthesis pathway can be profound. ${ }^{11,67}$

Our assay of control Neuro2a cells with several compounds known to affect the conversion of 7-DHC to cholesterol (DHCR7 in Figure 1) proved to be exquisitely sensitive and readily detects an increase in levels of 7-DHC in the cells at concentrations as low as $10 \mathrm{nM}$ for aripiprazole, trazodone, haloperidol, and AY9944. For reference, patient plasma concentrations of aripiprazole, trazodone, and haloperidol can be well above these levels. ${ }^{68-70}$ The effect of AY9944 on the cells was observed even at $1 \mathrm{nM}$, see Figure 4. Aripiprazole, trazodone, haloperidol, and AY9944 were all presumed "active" small molecules that affect sterol homeostasis at the DHCR7 step, ${ }^{25,26}$ and indeed, the assay identifies these compounds in the screen. ${ }^{37,71}$

AY9944 has been used as the basis for one SLOS rodent model. ${ }^{38}$ In this protocol, pregnant rats were exposed to carefully programmed levels of AY9944 during gestation and the exposure was continued in the pups for a period of up to three months. While the administration of high levels of AY9944 during pregnancy resulted in severe fetal malformation and miscarriage, carefully controlled maternal exposure of rats gave offspring that displayed many of the biochemical hallmarks and some of the phenotypic features of 
SLOS. ${ }^{32,34,38}$ Ratios of 7-DHC to cholesterol as high as 2:1 were found in the plasma and tissues of these SLOS pharmacological rat models. AY9944 failed as a cholesterol-lowering drug because it was found to be a teratogen, presumably due to its effect on cholesterol biosynthesis at the 7-DHC to cholesterol transformation. We note that other small molecules act in a way parallel to AY9944, and these compounds should be considered suspect teratogens based upon common metabolism. ${ }^{72}$

The Dhcr7-deficient Neuro2a cells demonstrate their primary utility as a first screen to identify compounds that decrease the formation of cellular 7-DHC. Table 2 shows the pharmaceutical action and prescription indication for those compounds identified in the NIH Clinical Collection that are approved for human use and that cause a decrease in 7-DHC in our screen of Dhcr 7-deficient cells. We also included a few additional compounds in the study that are not in the NIH Collection if there were reports of known activity or if they were structurally related to active compounds. Our screen confirms the notion that SERMs affect cholesterol biosynthesis by inhibiting the $\Delta 8-7$ isomerase and/or the DHCR2 4 because the sterol intermediates that accumulate upon treatment are those in the biosynthesis that are formed before the affected enzyme or enzymes (see Figure 9). ${ }^{63,64,73-77}$ The selectivity and specificity of action is dependent on the SERM structure and the cell type treated. Thus, as illustrated in Figure 7, treatment of SLOS skin fibroblasts with each of the SERMs resulted in a decrease of 7-DHC, but the levels of sterols such as desmosterol, 7dehydrodesmosterol, zymosterol, and zymostenol are affected to different extents by the different compounds. This can be understood by a more detailed consideration of the postlanosterol cholesterol biosynthesis scheme, see Figure 9. Levormefoxifene, bazedoxifene, and raloxifene increase levels of desmosterol and/or 7-dehydrodesmosterol in SLOS fibroblasts, indicating that DHCR24 is inhibited by these compounds. Clomiphene, tamoxifen, and toremifene increase levels of zymostenol and/or zymosterol, confirming that the $\Delta 8-7$ isomerase is inhibited. The main mechanism of action of SERMs is as estrogen receptor agonists in some tissues (bone, liver, and cardiovascular system), antagonists in other tissues (breast and brain), and mixed agonists/antagonists in the uterus. SERMs are primarily used for the prevention and treatment of breast cancer, osteoporosis, and menopausal symptoms. In addition to their endocrine actions on peripheral tissues and estrogen-dependent tumors, SERMs also affect the nervous system. They have been used in animal studies of different experimental models of neuronal dysfunction including traumatic CNS and PNS injury, multiple sclerosis, and stroke. On the basis of the limited information available from human studies some of SERMs may have a positive effect on mood and cognition. ${ }^{65}$ It has also been shown that SERMs affect several signaling proteins, including MAPK, PI3K, Akt, CREB, NFkB, and protein kinase $\mathrm{C}$, with the positive net effect in the animal studies of neuronal dysfunction. Through their effects on signaling proteins, SERMs have been shown to have beneficial effects on synaptic transmission, oxidative stress, apoptosis, and inflammation in the nervous system. They also bind to the hetero-oligomer of DHCR7 and DHCR24 (identified as the microsomal antiestrogen binding site) ${ }^{63}$ It is of some interest that side effects associated with some SERM therapies have resulted in withdrawal of a drug from the clinic. Levormeloxifene, for example, was discontinued during a phase III trial due to a significant incidence of gynecologic adverse events, although the cause of those events was not ascertained. ${ }^{78}$ 
The set of phenothiazines shown in Table 1 in row $3(\mathrm{~A}-\mathrm{D})$ and hydroxyzine (3E) (antipsychotics) have activities on sterol biosynthesis that parallel those of the SERMs. At submicromolar levels, each of these compounds reduce levels of 7-DHC in Dhcr7-deficient Neuro2a cells as well as in fibroblasts from SLOS patients. The apparent pharmacological activity of these closely related compounds lies primarily at the $\Delta 8-7$ isomerase and to a lesser extent the 24 reductase (Figure 9) because elevated levels of zymostenol and zymosterol are detected in incubations that include these compounds. The effect of antipsychotics on cholesterol and fatty acid metabolism is well documented. ${ }^{25}$ It has been suggested that some of antipsychotics have class II cationic amphiphilic properties similar to amphiphile U18666A and their cytotoxic effects are mediated by acting on cholesterol homeostasis. ${ }^{79}$ It is also of interest that prochloperazine, fluphenazine, and trifluoperazine, all of which affect the $\Delta 8-7$ isomerase, have been shown to be inhibitors of hepatitis $\mathrm{C}$ viral (HCV) entry by increasing target cell membrane fluidity. ${ }^{80,81}$ In a similar way, the SERMs toremifene and clomiphene inhibit ebola viral cell entry by a mechanism that affects the triggering of virion membrane fusion. ${ }^{82}$ It seems reasonable to suggest that the perturbation of sterol homeostasis and the consequential effect on membrane properties may underlie the mechanism of action for the phenothiazines with HCV and the SERMs with ebola.

\section{SUMMARY}

We conclude that an HTS screen of small molecules that affect sterol biosynthesis in control and Dhcr7-deficient Neuro2a cell cultures is feasible and our method provides a basis for the further exploration of compounds that alter sterol homeostasis. While the PTAD-LC-MS approach is selective and sensitive, the method does have limitations. Screens of large libraries at a range of concentrations is not possible with the current protocol because each assay requires about $1.5 \mathrm{~min}$ of instrument time. On the other hand, standard HTS instruments can be used in the assay, the workup of samples is straightforward, and multiple important sterol intermediates are determined in a single run. Because of these advantages, use of the PTAD-LC-MS approach proves useful when coupled with Dhcr7-deficient cells to identify compounds in small libraries that affect sterol biosynthesis at steps other than Dhcr 7 while screens of control Neuro2a reveal compounds that affect the conversion of 7-DHC to cholesterol. The approach may link small molecules that exert cellular toxicities with a specific disruption of cholesterol biosynthesis and it may lead to the identification of molecules that normalize cholesterol biosynthesis in disorders that disrupt normal cholesterol homeostasis.

Figure 10 provides a list of compounds that decrease 7-DHC at $1 \mu \mathrm{M}$ in Dhcr7-deficient Neuro2a cells as well as the sterol transformation affected by the compound. A screen of the NIH Collection at higher compound concentrations as well as a screen of larger libraries of pharmaceuticals and environmental agents that pose a threat to exposed populations seems likely to find other small molecules that affect sterol homeostasis. 


\section{EXPERIMENTAL SECTION}

\section{Materials}

Unless otherwise noted, all chemicals were purchased from Sigma-Aldrich Co (St. Louis, MO). HPLC grade solvents were purchased from Thermo Fisher Scientific Inc. (Waltham, MA). All cell culture reagents were from Mediatech (Manassas, VA), Life Technologies (Grand Island, NY), and Greiner Bio-One GmBH (Monroe, NC). Standard $d_{7}$-Chol was purchased from Medical Isotopes, Inc., and $d_{7}$-7-DHC was synthesized as previously described. ${ }^{41}{ }^{13} \mathrm{C}_{3}$-Lan and ${ }^{13} \mathrm{C}_{3}$-Des were synthesized as described in the Supporting Information.

\section{Compound Purity}

New compounds are characterized by HPLC-MS and ${ }^{13} \mathrm{C}$ and ${ }^{1} \mathrm{H}$ NMR spectroscopy and are $>98 \%$ purity by these methods of analysis. The NIH Clinical Collection of biologically active compounds is supplied by the NIH through the Molecular Libraries Roadmap Initiative, and it is curated by the Vanderbilt High Throughput Screening Facility and distributed in DMSO with $>95 \%$ purity. The compound molecular ion is identified by MS, and the samples are analyzed by HPLC with evaporative light scattering or UV detection. This collection is used widely in the screening community as a standard library.

\section{Cell Cultures: Neuro2a and Human Fibroblasts}

The neuroblastoma cell line Neuro2a was purchased from American Type Culture Collection (Rockville, MD). Dhcr7-deficient Neuro2a cells were generated as previously described. ${ }^{42}$ All cells were subcultured once a week, and the culture medium was changed every 2 days. Control (GM05399, GM05565, GM05758) and SLOS (GM05788, GM03044) human fibroblasts were purchased from the Coriell Institute, UMB727 was obtained from NICHD Brain and Tissue Bank, and 8019 and 35878 originated from SLOS patients. All cell lines were maintained in DMEM supplemented with L-glutamine, $10 \%$ fetal bovine serum (FBS; Thermo Scientific HyClone, Logan, UT), and penicillin/streptomycin at $37^{\circ} \mathrm{C}$ and $5 \% \mathrm{CO}_{2}$. All cultured SLOS and control human fibroblasts used were passage 8-20. Delipidated FBS medium did not have detectable cholesterol level. At the end of experiment, cells were washed with ice-cold PBS two times, scraped into $5 \mathrm{~mL}$ of ice-cold PBS, centrifuged at $200 \mathrm{~g}$ for $10 \mathrm{~min}$ at $+4{ }^{\circ} \mathrm{C}$, PBS removed, and the cell pellets frozen at $-80{ }^{\circ} \mathrm{C}$ until analysis.

\section{The Screening Method}

Chemicals were deposited to 384-cell culture plate (Greiner Bio-One) using Labcyte Echo 550/555 (Sunnyvale, CA) liquid handler equipped in the Vanderbilt University High Throughput Screening Facility. Then $25 \mu \mathrm{L}$ of control and Dhcr7-deficient Neuro2a cells in reduced FBS media (0.5\%) with a density of 10000 and 13000 cells/well, respectively, were dispensed to the wells using a Multidrop Combi (ThermoScientific) instrument. The cells were placed in an incubator for $24 \mathrm{~h}$, at which time $10 \mu \mathrm{L}$ of Hoechst dye $(40 \mathrm{ng} / \mu \mathrm{L})$ (Molecular Probes) was added using the Multidrop Combi. The cells were incubated at room temperature for $30 \mathrm{~min}$ in the dark and imaged using an ImageXpress Micro XL (Molecular 
Devices, Sunnyvale, CA) with a $10 \times$ objective. After removing the media, $80 \mu \mathrm{L}$ of $\mathrm{MeOH}$ containing internal standards ( $6.5 \mathrm{ng}$ for $d_{7}$-7-DHC, $100 \mathrm{ng}$ for ${ }^{13} \mathrm{C}_{3}$-Des, and $75 \mathrm{ng}$ for ${ }^{13} \mathrm{C}_{3}$-Lano/well) were added using the Multidrop Combi. The plate was placed on an Orbital shaker for $20 \mathrm{~min}$ at room temperature and centrifuged for $10 \mathrm{~min}$ using a Sorvall swing rotor. The supernatant was transferred by automated liquid handler Agilent Velocity 11 Bravo to a PTAD-predeposited plate (Waters no. 186002631, $100 \mu \mathrm{L}$ flat bottom). The plates were immediately sealed with Easy Pierce Heat Sealing Foil (ThermoScientific AB-1720), followed by 20 min agitation on an Orbital shaker at room temperature. The sealed plates were kept in $-80{ }^{\circ} \mathrm{C}$ until LC-MS analysis.

\section{LC-MS (SRM) Analysis}

The sealed plates were placed in an Acquity UPLC system equipped with ANSI-compliant well plate holder. Then $10 \mu \mathrm{L}$ was injected on to the column (Acquity UPLC BEH C18, 1.7 $\mu \mathrm{m}, 2.1 \mathrm{~mm} \times 50 \mathrm{~mm})$ with $100 \% \mathrm{MeOH}(0.1 \%$ acetic acid) mobile phase for $1 \mathrm{~min}$ runtime at a flow rate of $300 \mu \mathrm{L} / \mathrm{min}$. The monitored transitions included: 7-DHC $560 \rightarrow 365, d_{7}-7-$ DHC $567 \rightarrow 372$, desmosterol $592 \rightarrow 365,{ }^{13} \mathrm{C}_{3}$-desmosterol $595 \rightarrow 368$, lanosterol $634 \rightarrow$ 602 , and ${ }^{13} \mathrm{C}_{3}$-lanosterol $637 \rightarrow 605$ with retention times of $0.8,0.5$, and $0.6 \mathrm{~min}$, respectively.

\section{Lipid Extraction, Separation, and GC-MS Analyses of Sterols in Cells}

Verification of the hits obtained from the initial screening was carried out with varying concentrations of the compounds of interest. In addition, a more complete sterol profile was determined. The experiment was carried out in 96-well plates as described above for the 384-well plates. After cells were counted using the ImageXpress Micro XL with 10x objective, the medium was removed. The cells were washed with PBS, the buffer was removed, and the plates were stored at $-80{ }^{\circ} \mathrm{C}$ until taken for sterol analysis. The protocol for analysis was as follows: to each well was added $10 \mu \mathrm{L}$ of BHT/TPP solution (2.5 mg of TPP and $1 \mathrm{mg}$ of BHT in $1 \mathrm{~mL}$ of EtOH), $10 \mu \mathrm{L}$ of internal standard solution $(0.87 \mathrm{nmol}$ for $d_{7}$-Chol, $0.033 \mathrm{nmol}$ for $d_{7}$-7-DHC, $0.25 \mathrm{nmol}$ for ${ }^{13} \mathrm{C}_{3}$-Des, and $0.23 \mathrm{nmol}$ for ${ }^{13} \mathrm{C}_{3}$-Lan/ well), and $200 \mu \mathrm{L}$ of $\mathrm{MeOH}$. The plate was agitated on an Orbital shaker for $20 \mathrm{~min}$ at room temperature. An aliquot $(100 \mu \mathrm{L})$ of the supernatant was transferred to a PTAD-predeposited plate, sealed with Easy Pierce Heat Sealing Foil followed by 20 min agitation on an Orbital shaker at room temperature, and analyzed by LC-MS as described above. If the LC flow rate was increased to $500 \mu \mathrm{L} / \mathrm{min}$ with a run time of $1.5 \mathrm{~min}$, cholesterol could be included in the analysis (Chol 369, $d_{7}$-Chol 376).

For GC-MS analysis, the remaining sample in each well was transferred to a vial and concentrated on a SpeedVac concentrator. To each vial was added $N, O$-bis(trimethylsilyl)trifluoroacetamide (BSTFA, $50 \mu \mathrm{L}$ ), the sample vortexed well, and allowed to react for 30 min. The sample $(5 \mu \mathrm{L})$ was injected onto the column (SPB-5, $0.25 \mu \mathrm{m}, 0.32 \mathrm{~mm} \times 30 \mathrm{~m}$ ) with a temperature program of $220-300^{\circ}(5 \mathrm{~min})$ at $20^{\circ} / \mathrm{min}$ and helium flow rate of $2.0 \mathrm{~mL} /$ $\mathrm{min}$. The data was collected in full scan mode and the following ions extracted for quantitation relative to $d_{7}$-Chol: 458 for cholesterol, zymostenol, and lathosterol; 456 for zymosterol and dehydrolathosterol; 349 (M-105) for dehydrodesmosterol; 393 (M-105) for lanosterol; 395 (M-105) for dihydrolanosterol; 486 for dimethylzymostenol; and 465 for $d_{7}$ - 
cholesterol. Desmosterol and 7-DHC were not analyzed by GC-MS because they coelute. Any sterol not listed above was not detected by GC-MS. All data was normalized to cell count. All calculations of variability, standard deviation (SD), and normalized SD were performed in Microsoft Excel or GraphPad Prism.

\section{Supplementary Material}

Refer to Web version on PubMed Central for supplementary material.

\section{Acknowledgments}

We thank Dr. H. Ronald Zielke and UMB Brain and Tissue Bank/NIH NeuroBioBank for donation of UMB727 (http://medschool.umaryland.edu/btbank/). The National Institutes of Health (NICHD R01 HD064727 to N.A.P., NIEHS R01 ES024133 to N.A.P. and Z.K., R21 ES024666 to N.A.P.) and the Hungarian Research Fund OTKA K109076 to I.B. supported this work. Assay development and preparation was carried out with assistance from Paige Vinson and Joshua Bauer in the Vanderbilt High-throughput Screening Core Facility, which receives institutional support through the Vanderbilt Institute of Chemical Biology. The NIH Clinical Collection is provided through the National Institutes of Health Molecular Libraries Roadmap Initiative.

\section{ABBREVIATIONS USED}

7-DHC

Des

Lan

Chol

dHLan

Zym

Zyme

dMZyme

dHLath

Lath

DHD

PTAD

SLOS

DHCR7

DHCR24

EBP

HMG-CoA

MS

APCI

SRM 7-dehydrocholesterol

desmosterol

lanosterol

cholesterol

24-dihydrolanosterol

zymosterol

zymostenol

4,4-dimethylzymostenol

24-dehydrolathosterol

lathosterol

7-dehydrodesmosterol

4-phenyl-1,2,4-triazoline-3,5-dione

Smith-Lemli-Opitz syndrome

7-dehydrocholesterol reductase

24-dehydrocholesterol reductase

emopamil binding protein

hydroxymethyl glutaryl-coenzyme A

mass spectrometry

atmospheric pressure chemical ionization

selected reaction monitoring 


$\begin{array}{ll}\text { UPLC-MS } & \text { ultrahigh pressure liquid chromatography-mass spectrometry } \\ \text { HPLC-UV } & \text { high pressure liquid chromatography-ultraviolet spectroscopy } \\ \text { MeOH } & \text { methanol } \\ \text { NMR } & \text { nuclear magnetic resonance } \\ \text { TIC } & \text { total ion current } \\ \text { FBS } & \text { fetal bovine serum } \\ \text { DMEM } & \text { Dulbecco's Modified Eagle Medium } \\ \text { PBS } & \text { phosphate buffered saline } \\ \text { DMSO } & \text { dimethyl sulfoxide } \\ \text { HTS } & \text { high throughput screening } \\ \text { SERM } & \text { selective estrogen receptor modulator } \\ \text { HF } & \text { human fibroblasts } \\ \text { CNS } & \text { central nervous system } \\ \text { PNS } & \text { peripheral nervous system } \\ \text { MAPK } & \text { mitogen-activated protein kinase } \\ \text { PI3K } & \text { phosphoinositide 3-kinase } \\ \text { CREB } & \text { cAMP response element-binding protein } \\ \text { NFkB } & \text { nuclear factor } \kappa \text { light-chain-enhancer of activated B cells }\end{array}$

\section{REFERENCES}

1. Nes WD. Biosynthesis of cholesterol and other sterols. Chem. Rev. 2011; 111:6423-6451. [PubMed: 21902244]

2. Koide T, Hayata T, Cho KW. Negative regulation of Hedgehog signaling by the cholesterogenic enzyme 7-dehydrocholesterol reductase. Development. 2006; 133:2395-2405. [PubMed: 16687448]

3. Lauth M, Rohnalter V, Bergstrom A, Kooshesh M, Svenningsson P, Toftgard R. Antipsychotic drugs regulate hedgehog signaling by modulation of 7-dehydrocholesterol reductase levels. Mol. pharmacol. 2010; 78:486-496. [PubMed: 20558592]

4. Stottmann RW, Turbe-Doan A, Tran P, Kratz LE, Moran JL, Kelley RI, Beier DR. Cholesterol metabolism is required for intracellular hedgehog signal transduction in vivo. PLoS Genet. 2011; 7:e1002224. [PubMed: 21912524]

5. Herman GE. Disorders of cholesterol biosynthesis: prototypic metabolic malformation syndromes. Hum. Mol. Genet. 2003; 12(Suppl 1):R75-R88. [PubMed: 12668600]

6. Javitt NB. Oxysterols: novel biologic roles for the 21st century. Steroids. 2008; 73:149-157. [PubMed: 18068744]

7. Smith DW, Lemli L, Opitz JM. A newly recognized syndrome of multiple congenital anomalies. J. Pediatr. 1964; 64:210-217. [PubMed: 14119520]

8. Honda A, Tint GS, Salen G, Batta AK, Chen TS, Shefer S. Defective conversion of 7dehydrocholesterol to cholesterol in cultured skin fibroblasts from Smith-Lemli-Opitz syndrome homo-zygotes. J. Lipid Res. 1995; 36:1595-1601. [PubMed: 7595082] 
9. Tint GS, Seller M, Hughes-Benzie R, Batta AK, Shefer S, Genest D, Irons M, Elias E, Salen G. Markedly increased tissue concentrations of 7-dehydrocholesterol combined with low levels of cholesterol are characteristic of the Smith-Lemli-Optiz syndrome. J. Lipid Res. 1995; 36:89-95. [PubMed: 7706951]

10. Kanungo S, Soares N, He M, Steiner RD. Sterol metabolism disorders and neurodevelopment—an update. Develop. Dis. Res. Rev. 2013; 17:197-210.

11. Porter FD, Herman GE. Malformation syndromes caused by disorders of cholesterol synthesis. J. Lipid Res. 2011; 52:6-34. [PubMed: 20929975]

12. Andersson HC, Kratz L, Kelley RI. Desmosterolosis presenting with multiple congenital anomalies and profound developmental delay. Am. J. Med. Genet. 2002; 113:315-319. [PubMed: 12457401]

13. FitzPatrick DR, Keeling JW, Evans MJ, Kan AE, Bell JE, Porteous ME, Mills K, Winter RM, Clayton PT. Clinical phenotype of desmosterolosis. Am. J. Med. Genet. 1998; 75:145-152. [PubMed: 9450875]

14. Schaaf CP, Koster J, Katsonis P, Kratz L, Shchelochkov DA, Scaglia F, Kelley RI, Lichtarge O, Waterham HR, Shinawi M. Desmosterolosis-phenotypic and molecular characterization of a third case and review of the literature. Am. J. Med. Genet, Part A. 2011; 155:1597-1604. [PubMed: 21671375]

15. Waterham HR, Koster J, Romeijn GJ, Hennekam RC, Vreken P, Andersson HC, FitzPatrick DR, Kelley RI, Wanders RJA. Mutations in the 3beta-hydroxysterol Delta24-reductase gene cause desmosterolosis, an autosomal recessive disorder of cholesterol biosynthesis. Am. J. Hum. Genet. 2001; 69:685-694. [PubMed: 11519011]

16. Zolotushko J, Flusser H, Markus B, Shelef I, Langer Y, Heverin M, Bjorkhem I, Sivan S, Birk OS. The desmosterolosis phenotype: spasticity, microcephaly and micrognathia with agenesis of corpus callosum and loss of white matter. Eur. J. Hum. Genet. 2011; 19:942-946. [PubMed: 21559050]

17. Haas D, Garbade SF, Vohwinkel C, Muschol N, Trefz FK, Penzien JM, Zschocke J, Hoffmann GF, Burgard P. Effects of cholesterol and simvastatin treatment in patients with Smith-Lemli-Opitz syndrome (SLOS). J. Inherited Metab. Dis. 2007; 30:375-387. [PubMed: 17497248]

18. Chan YM, Merkens LS, Connor WE, Roullet JB, Penfield JA, Jordan JM, Steiner RD, Jones PJ. Effects of dietary cholesterol and simvastatin on cholesterol synthesis in Smith-Lemli-Opitz syndrome. Pediatr. Res. 2009; 65:681-685. [PubMed: 19430384]

19. Szabo GP, Olah AV, Kozak L, Balogh E, Nagy A, Blahakova I, Olah E. A patient with SmithLemli-Opitz syndrome: novel mutation of the DHCR7 gene and effects of therapy with simvastatin and cholesterol supplement. Eur. J. Pediatr. 2010; 169:121-123. [PubMed: 19365639]

20. Xu L, Davis TA, Porter NA. Rate constants for peroxidation of polyunsaturated fatty acids and sterols in solution and in liposomes. J. Am. Chem. Soc. 2009; 131:13037-13044. [PubMed: 19705847]

21. Xu L, Korade Z, Porter NA. Oxysterols from free radical chain oxidation of 7-dehydrocholesterol: product and mechanistic studies. J. Am. Chem. Soc. 2010; 132:2222-2232. [PubMed: 20121089]

22. Xu L, Mirnics K, Bowman AB, Liu W, Da J, Porter NA, Korade Z. DHCEO accumulation is a critical mediator of pathophysiology in a Smith-Lemli-Opitz syndrome model. Neurobiol. Dis. 2012; 45:923-929. [PubMed: 22182693]

23. Korade Z, Xu L, Shelton R, Porter NA. Biological activities of 7-dehydrocholesterol-derived oxysterols: implications for Smith-Lemli-Opitz syndrome. J. Lipid Res. 2010; 51:3259-3269. [PubMed: 20702862]

24. Waage-Baudet H, Lauder JM, Dehart DB, Kluckman K, Hiller S, Tint GS, Sulik KK. Abnormal serotonergic development in a mouse model for the Smith-Lemli-Opitz syndrome: implications for autism. Int. J. Dev. Neurosci. 2003; 21:451-459. [PubMed: 14659996]

25. Canfran-Duque A, Casado ME, Pastor O, Sanchez-Wandelmer J, de la Pena G, Lerma M, Mariscal P, Bracher F, Lasuncion MA, Busto R. Atypical antipsychotics alter cholesterol and fatty acid metabolism in vitro. J. Lipid Res. 2013; 54:310-324. [PubMed: 23175778]

26. Hall P, Michels V, Gavrilov D, Matern D, Oglesbee D, Raymond K, Rinaldo P, Tortorelli S. Aripiprazole and trazodone cause elevations of 7-dehydrocholesterol in the absence of SmithLemli-Opitz Syndrome. Mol. Genet. Metab. 2013; 110:176-178. [PubMed: 23628460] 
27. Krakowski MI, Czobor P. A prospective longitudinal study of cholesterol and aggression in patients randomized to clozapine, olanzapine, and haloperidol. J. Clin. Psychopharmacol. 2010; 30:198-200. [PubMed: 20520296]

28. Krakowski M, Czobor P. Cholesterol and cognition in schizophrenia: a double-blind study of patients randomized to clozapine, olanzapine and haloperidol. Schizophr. Res. Treat. 2011; 130:27-33.

29. de Medina P, Paillasse MR, Segala G, Poirot M, Silvente-Poirot S. Identification and pharmacological characterization of cholesterol-5,6-epoxide hydrolase as a target for tamoxifen and AEBS ligands. Proc. Natl. Acad. Sci. U. S. A. 2010; 107:13520-13525. [PubMed: 20615952]

30. Payre B, de Medina P, Boubekeur N, Mhamdi L, Bertrand-Michel J, Terce F, Fourquaux I, Goudouneche D, Record M, Poirot M, Silvente-Poirot S. Microsomal antiestrogen-binding site ligands induce growth control and differentiation of human breast cancer cells through the modulation of cholesterol metabolism. Mol. Cancer Ther. 2008; 7:3707-3718. [PubMed: 19074846]

31. Moebius FF, Fitzky BU, Lee JN, Paik YK, Glossmann H. Molecular cloning and expression of the human delta7-sterol reductase. Proc. Natl. Acad. Sci. U. S. A. 1998; 95:1899-1902. [PubMed: 9465114]

32. Fliesler SJ, Richards MJ, Miller C, Peachey NS. Marked alteration of sterol metabolism and composition without compromising retinal development or function. Invest. Ophthalmol. Visual Sci. 1999; 40:1792-1801. [PubMed: 10393050]

33. Gofflot F, Kolf-Clauw M, Clotman F, Roux C, Picard JJ. Absence of ventral cell populations in the developing brain in a rat model of the Smith-Lemli-Opitz syndrome. Am. J. Med. Genet. 1999; 87:207-216. [PubMed: 10564872]

34. Fliesler SJ, Peachey NS, Richards MJ, Nagel BA, Vaughan DK. Retinal degeneration in a rodent model of Smith-Lemli-Opitz syndrome: electrophysiologic, biochemical, and morphologic features. Arch. Ophthalmol. 2004; 122:1190-1200. [PubMed: 15302661]

35. Vaughan DK, Peachey NS, Richards MJ, Buchan B, Fliesler SJ. Light-induced exacerbation of retinal degeneration in a rat model of Smith-Lemli-Opitz syndrome. Exp. Eye Res. 2006; 82:496504. [PubMed: 16360150]

36. Boesze-Battaglia K, Damek-Poprawa M, Mitchell DC, Greeley L, Brush RS, Anderson RE, Richards MJ, Fliesler SJ. Alteration of retinal rod outer segment membrane fluidity in a rat model of Smith-Lemli-Opitz syndrome. J. Lipid Res. 2008; 49:1488-1499. [PubMed: 18344409]

37. Ford DA, Monda JK, Brush RS, Anderson RE, Richards MJ, Fliesler SJ. Lipidomic analysis of the retina in a rat model of Smith-Lemli-Opitz syndrome: alterations in docosahexaenoic acid content of phospholipid molecular species. J. Neurochem. 2008; 105:1032-1047. [PubMed: 18182048]

38. Fliesler SJ. Retinal degeneration in a rat model of smith-lemli-opitz syndrome: thinking beyond cholesterol deficiency. Adv. Exp. Med. Biol. 2010; 664:481-489. [PubMed: 20238050]

39. Xu L, Liu W, Sheflin LG, Fliesler SJ, Porter NA. Novel oxysterols observed in tissues and fluids of AY9944-treated rats - a model for Smith-Lemli-Opitz Syndrome. J. Lipid Res. 2011; 52:1810 1820. [PubMed: 21817059]

40. Xu L, Sheflin LG, Porter NA, Fliesler SJ. 7-Dehydrocholesterol-derived oxysterols and retinal degeneration in a rat model of Smith-Lemli-Opitz syndrome. Biochim. Biophys. Acta, Mol. Cell Biol. Lipids. 2012; 1821:877-883.

41. Xu L, Korade Z, Rosado DA Jr, Liu W, Lamberson CR, Porter NA. An oxysterol biomarker for 7dehydrocholesterol oxidation in cell/mouse models for Smith-Lemli-Opitz syndrome. J. Lipid Res. 2011; 52:1222-1233. [PubMed: 21402677]

42. Korade Z, Kenworthy AK, Mirnics K. Molecular consequences of altered neuronal cholesterol biosynthesis. J. Neurosci. Res. 2009; 87:866-875. [PubMed: 18951487]

43. Evangelopoulos ME, Wuller S, Weis J, Kruttgen A. A role of nitric oxide in neurite outgrowth of neuroblastoma cells triggered by mevastatin or serum reduction. Neurosci. Lett. 2010; 468:28-33. [PubMed: 19853642]

44. Windsor K, Genaro-Mattos TC, Kim HY, Liu W, Tallman KA, Miyamoto S, Korade Z, Porter NA. Probing lipid-protein adduction with alkynyl surrogates: application to Smith-Lemli-Opitz syndrome. J. Lipid Res. 2013; 54:2842-2850. [PubMed: 23828810] 
45. Umeda T, Mori H, Zheng H, Tomiyama T. Regulation of cholesterol efflux by amyloid beta secretion. J. Neurosci. Res. 2010; 88:1985-1994. [PubMed: 20155813]

46. Klein A, Mosqueira M, Martínez G, Robledo F, González M, Caballero B, Cancino GI, Alvarez AR, Hetz C, Zanlungo S. Lack of activation of the unfolded protein response in mouse and cellular models of Niemann-Pick type C disease. Neurodegener. Dis. 2011; 8:124-128. [PubMed: 20714112]

47. Liu W, Xu L, Lamberson C, Haas D, Korade Z, Porter NA. A highly sensitive method for analysis of 7-dehydrocholesterol for the study of Smith-Lemli-Opitz syndrome. J. Lipid Res. 2014; 55:329-337. [PubMed: 24259532]

48. Barton DHR, Shioiri T, Widdowson DA. Biosynthesis of terpenes and steroids. V. Synthesis of ergosta-5,7,22,24(28)-tetraen-3ß-ol, a biosynthetic precursor of ergosterol. J. Chem. Soc. C. 1971:1968-1974.

49. Kim HS, Wilson WK, Needleman DH, Pinkerton FD, Wilson DK, Quiocho FA, Schroepfer GJ. Inhibitors of sterol synthesis. Chemical synthesis, structure, and biological activities of (25R)-3 $\beta$, 26-dihydroxy-5a-cholest-8(14)-en-15-one, a metabolite of 3 $\beta$-hydroxy-5a-cholest-8(14)-en-15one. J. Lipid Res. 1989; 30:247-261. [PubMed: 2715729]

50. Johnson DW, ten Brink HJ, Jakobs C. A rapid screening procedure for cholesterol and dehydrocholesterol by electrospray ionization tandem mass spectrometry. J. Lipid Res. 2001; 42:1699-1705. [PubMed: 11590227]

51. Higashi T, Shimada K, Toyo'oka T. Advances in determination of vitamin D related compounds in biological samples using liquid chromatography-mass spectrometry: A review. J. Chromatogr. B: Anal. Technol. Biomed. Life Sci. 2010; 878:1654-1661.

52. Aronov PA, Hall LM, Dettmer K, Stephensen CB, Hammock BD. Metabolic profiling of major vitamin D metabolites using Diels-Alder derivatization and ultra-performance liquid chromatography-tandem mass spectrometry. Anal. Bioanal. Chem. 2008; 391:1917-1930. [PubMed: 18437365]

53. Elemes Y, Orfanopoulos M. Triazolinedione Additions to Alkenes in Protic Solvents. A Remarkable Temperature Dependence of the Competing Reaction Paths. Tetrahedron Lett. 1991; 32:2667-2670.

54. Alberti MN, Orfanopoulos M. Concerning the Reactivity of PTAD with Isomeric Dienes: The Mechanism of the Diels-Alder Cycloaddition. Org. Lett. 2009; 11:1659-1662. [PubMed: 19281199]

55. Roubelakis MM, Vougioukalakis GC, Angelis YS, Orfanopoulos M. Solvent-Dependent Changes in the Ene Reaction of RTAD with Alkenes: The Cyclopropyl Group as a Mechanistic Probe. Org. Lett. 2006; 8:39-42. [PubMed: 16381562]

56. Vougioukalakis GC, Orfanopoulos M. Mechanistic Studies in Triazolinedione Ene Reactions. Synlett. 2005:0713-0731.

57. Vougioukalakis GC, Roubelakis MM, Alberti MN, Orfanopoulos M. Solvent-Dependent Changes in the Triazolinedione-Alkene Ene Reaction Mechanism. Chem. - Eur. J. 2008; 14:9697-9705. [PubMed: 18816558]

58. Melkersson K, Dahl ML. Adverse metabolic effects associated with atypical antipsychotics: literature review and clinical implications. Drugs. 2004; 64:701-723. [PubMed: 15025545]

59. Meyer U, Spoerri E, Yee BK, Schwarz MJ, Feldon J. Evaluating Early Preventive Antipsychotic and Antidepressant Drug Treatment in an Infection-Based Neurodevelopmental Mouse Model of Schizophrenia. Schizophr. Bull. 2010; 36:607-623. [PubMed: 18845557]

60. U.S. Pharmaceutical Sales-Q4 2013; Drugs.com. 2014 Feb. http://www.drugs.com/stats/top100/ sales

61. Zhang J-H, Chung TD, Oldenburg K. R A Simple Statistical Parameter for Use in Evaluation and Validation of High Throughput Screening Assays. J. Biomol. Screening. 1999; 4:67-73.

62. Lee J, Lee J, Jung E, Cho JY, Park D. Artemisinic acid inhibits melanogenesis through downregulation of C/EBP a-dependent expression of HMG-CoA reductase gene. Food Chem. Toxicol. 2013; 51:225-230. [PubMed: 23063590]

63. Polymeropoulos MH, Licamele L, Volpi S, Mack K, Mitkus SN, Carstea ED, Getoor L, Thompson A, Lavedan C. Common effect of antipsychotics on the biosynthesis and regulation of fatty acids 
and cholesterol supports a key role of lipid homeostasis in schizophrenia. Schizophr. Res. 2009; 108:134-142. [PubMed: 19150222]

64. Horvat S, McWhir J, Rozman D. Defects in cholesterol synthesis genes in mouse and in humans: lessons for drug development and safer treatments. Drug Metab. Rev. 2011; 43:69-90. [PubMed: 21247357]

65. Arevalo MA, Santos-Galindo M, Lagunas N, Azcoitia I, Garcia-Segura LM. Selective estrogen receptor modulators as brain therapeutic agents. J. Mol. Endocrinol. 2011; 46:R1-R9. [PubMed: 21071476]

66. Zerenturk EJ, Sharpe LJ, Ikonen E, Brown AJ. Desmosterol and DHCR24: unexpected new directions for a terminal step in cholesterol synthesis. Prog. Lipid Res. 2013; 52:666-680. [PubMed: 24095826]

67. Linck LM, Hayflick SJ, Lin DS, Battaile KP, Ginat S, Burlingame T, Gibson KM, Honda M, Honda A, Salen G, Tint GS, Connor WE, Steiner RD. Fetal demise with Smith-Lemli-Opitz syndrome confirmed by tissue sterol analysis and the absence of measurable 7-dehydrocholesterol A7-reductase activity in chorionic villi. Prenatal Diagn. 2000; 20:238-240.

68. Windhager E, Kim SW, Saria A, Zauner K, Amminger PG, Klier CM. Perinatal use of aripiprazole: plasma levels, placental transfer, and child outcome in 3 new cases. J. Clin. Psychopharmacol. 2014; 34:637-641. [PubMed: 24949701]

69. Choong E, Rudaz S, Kottelat A, Haldemann S, Guillarme D, Veuthey JL, Eap CB. Quantification of 4 antidepressants and a metabolite by LC-MS for therapeutic drug monitoring. J. Chromatogr. B: Anal. Technol. Biomed. Life Sci. 2011; 879:1544-1550.

70. Aymard N, Viala A, Stein I, Caroli F. Pharmacoclinical correlations in schizophrenic patients treated with haloperidol decanoate: clinical evaluations, concentrations of plasma and red blood cell haloperidol and its reduced metabolite, and plasma homovanillic acid. Prog. NeuroPsychopharmacol. Biol. Psychiatry. 1995; 19:1119-1135.

71. Fliesler SJ, Bretillon L. The ins and outs of cholesterol in the vertebrate retina. J. Lipid Res. 2010; 51:3399-3413. [PubMed: 20861164]

72. Horling A, Muller C, Barthel R, Bracher F, Imming P. A new class of selective and potent 7dehydrocholesterol reductase inhibitors. J. Med. Chem. 2012; 55:7614-7622. [PubMed: 22882119]

73. Moebius FF, Fitzky BU, Wietzorrek G, Haidekker A, Eder A, Glossmann H. Cloning of an emopamil-binding protein (EBP)-like protein that lacks sterol $\Delta 8-\Delta 7$ isomerase activity. Biochem. J. 2003; 374:229. [PubMed: 12760743]

74. Moebius FF, Reiter RJ, Hanner M, Glossmann H. High affinity of sigma 1-binding sites for sterol isomerization inhibitors: evidence for a pharmacological relationship with the yeast sterol C 8-C 7isomerase. Br. J. Pharmacol. 1997; 121:1-6. [PubMed: 9146879]

75. Holleran AL, Lindenthal B, Aldaghlas TA, Kelleher JK. Effect of tamoxifen on cholesterol synthesis in HepG2 cells and cultured rat hepatocytes. Metab., Clin. Exp. 1998; 47:1504-1513. [PubMed: 9867082]

76. Turner RT, Evans GL, Sluka JP, Adrian MD, Bryant HU, Turner CH, Sato M. Differential responses of estrogen target tissues in rats including bone to clomiphene, enclomiphene, and zuclomiphene. Endocrinology. 1998; 139:3712-3720. [PubMed: 9724022]

77. Garola R, Levy CM, Vegh I, Magin C, Martinez JC, Hecker E. In vivo blockade of the estradiolbinding-protein (EBP) by clomiphene citrate in human breast cancer. Oncology. 1974; 30:105112.

78. Ravn P, Nielsen TF, Christiansen C. What can be learned from the levormeloxifene experience? Acta Obstet. Gynecol. Scand. 2006; 85:135-142. [PubMed: 16532904]

79. Wiklund ED, Catts VS, Catts SV, Ng TF, Whitaker NJ, Brown AJ, Lutze-Mann LH. Cytotoxic effects of antipsychotic drugs implicate cholesterol homeostasis as a novel chemotherapeutic target. Int. J. Cancer. 2010; 126:28-40. [PubMed: 19662652]

80. Chamoun-Emanuelli AM, Pecheur E-I, Simeon RL, Huang D, Cremer PS, Chen Z. Phenothiazines inhibit hepatitis $\mathrm{C}$ virus entry, likely by increasing the fluidity of cholesterol-rich membranes. Antimicrob. Agents Chemother. 2013; 57:2571-2581. [PubMed: 23529728] 
81. Perin PM, Haid S, Brown RJP, Doerrbecker J, Schulze K, Zeilinger C, von Schaewen M, Heller B, Vercauteren K, Luxenburger E, Baktash YM, Vondran FWR, Speerstra S, Awadh A, Mukhtarov F, Schang LM, Kirschning A, Müller R, Guzman CA, Kaderali L, Randall G, Meuleman P, Ploss A, Pietschmann T. Flunarizine Prevents Hepatitis C Virus Membrane Fusion in a Genotypedependent Manner by Targeting the Potential Fusion Peptide within E1. Hepatology. 2016; 63:49_ 62. [PubMed: 26248546]

82. Johansen LM, Brannan JM, Delos SE, Shoemaker CJ, Stossel A, Lear C, Hoffstrom BG, DeWald LE, Schornberg KL, Scully C, Lehár J, Hensley LE, White JM, Olinger GG. FDA-approved selective estrogen receptor modulators inhibit Ebola virus infection. Sci. Transl. Med. 2013; 5:190ra79. 


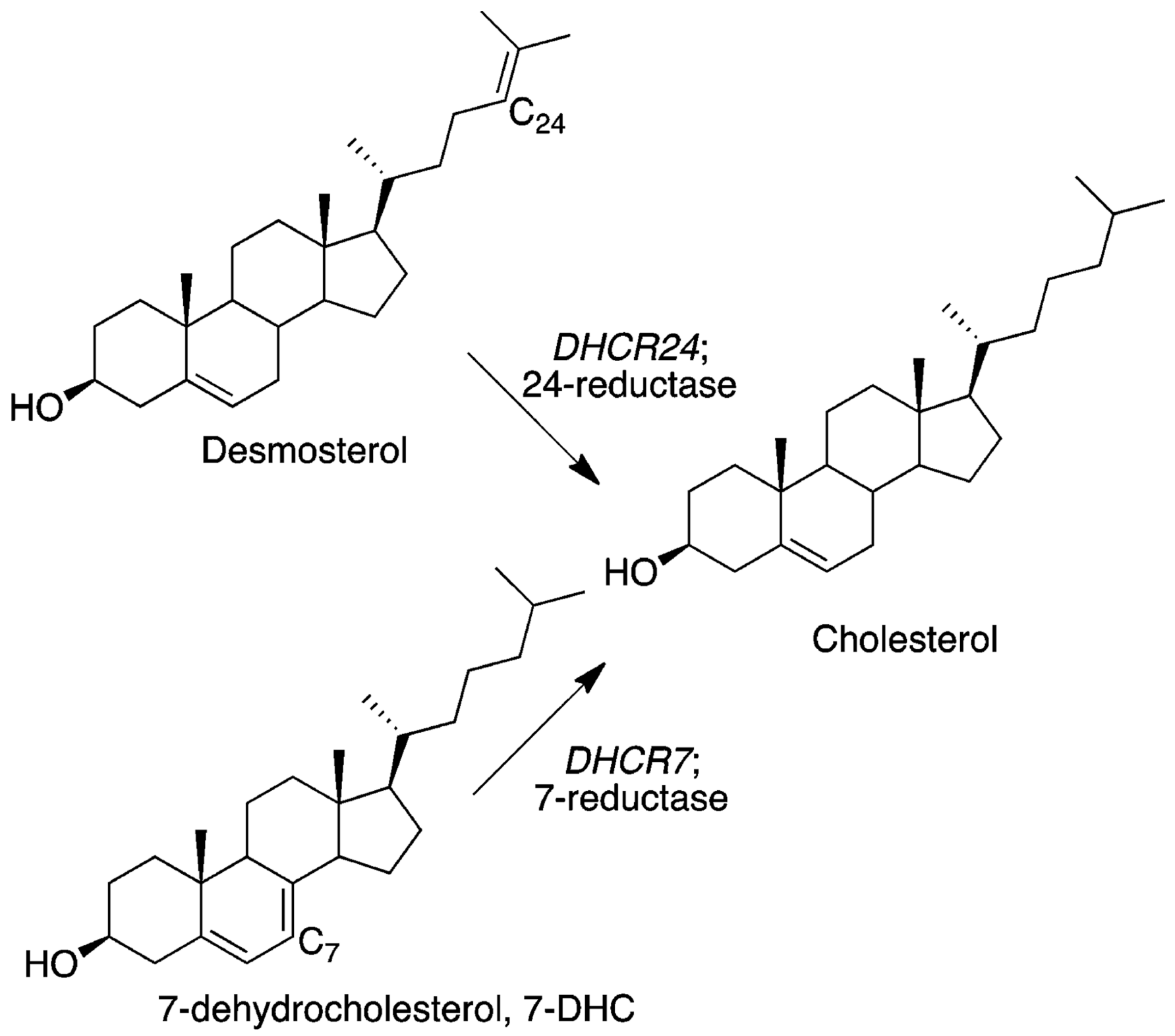

Figure 1.

Late-stage sterols in cholesterol biosynthesis. 


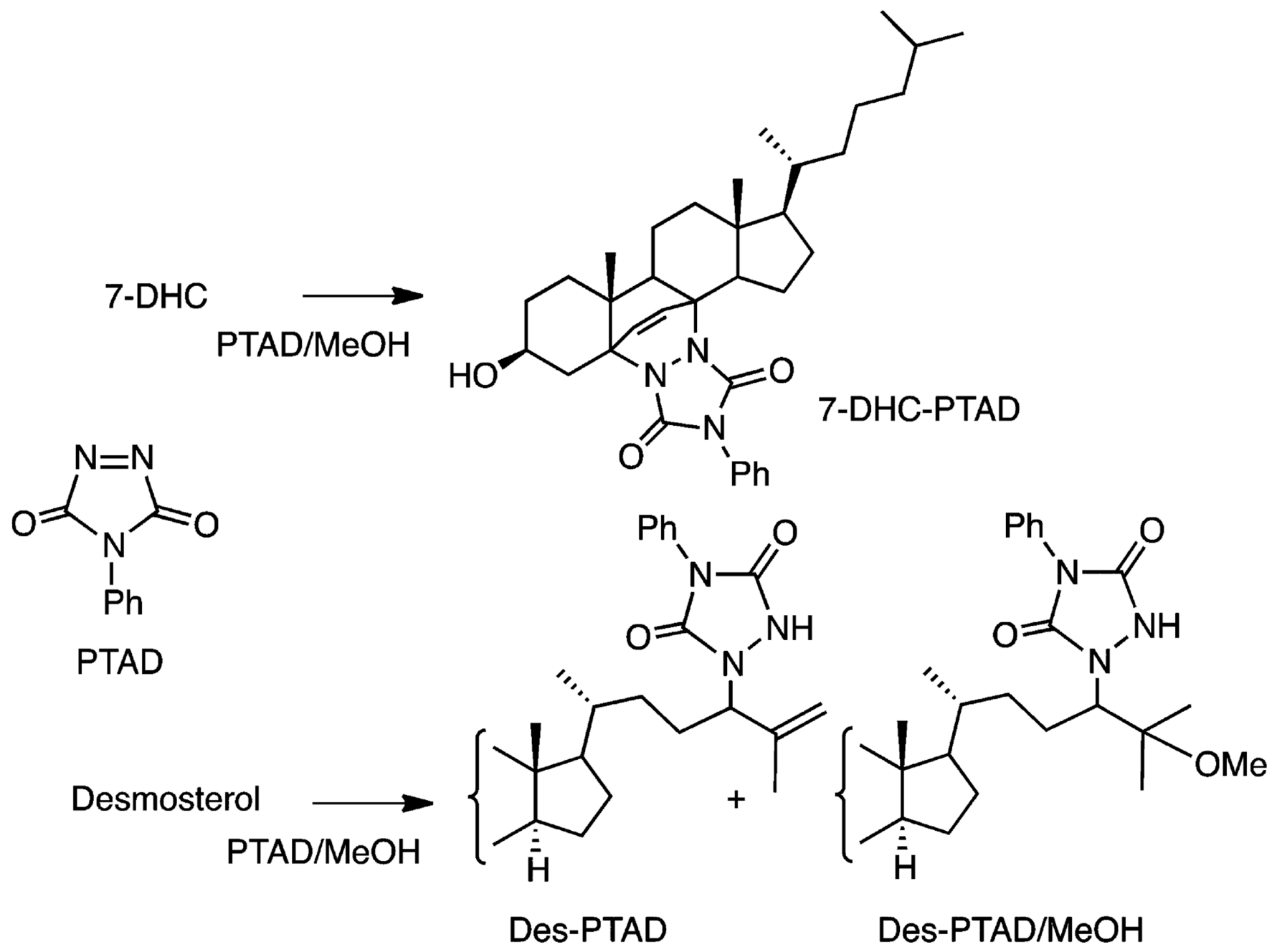

Figure 2.

PTAD, its 7-DHC Diels-Alder adduct (7-DHC-PTAD), and the desmosterol products of PTAD in methanol. 


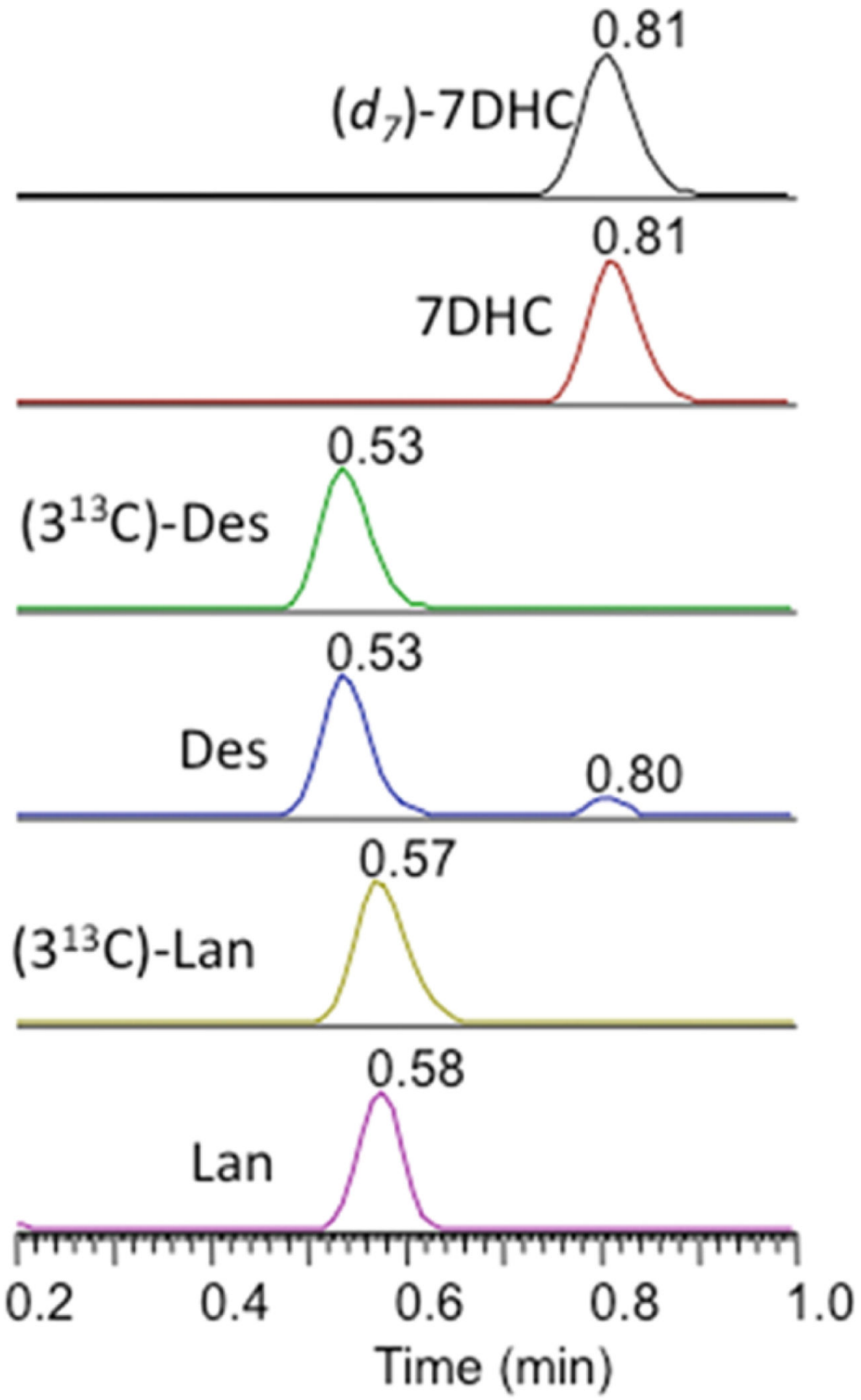

Figure 3.

UPLC-MS chromatogram of PTAD assay for Dhcr7-deficient Neuro2a cells. Shown are selective reaction monitoring of 7-DHC and its isotopic standard $\left(d_{7}-7 \mathrm{DHC}\right)$, desmosterol (Des), lanosterol (Lan), and their ${ }^{13} \mathrm{C}$-isotopic standards $\left(3^{13} \mathrm{C}\right.$-Des) and $\left(3^{13} \mathrm{C}-\mathrm{Lan}\right)$. 


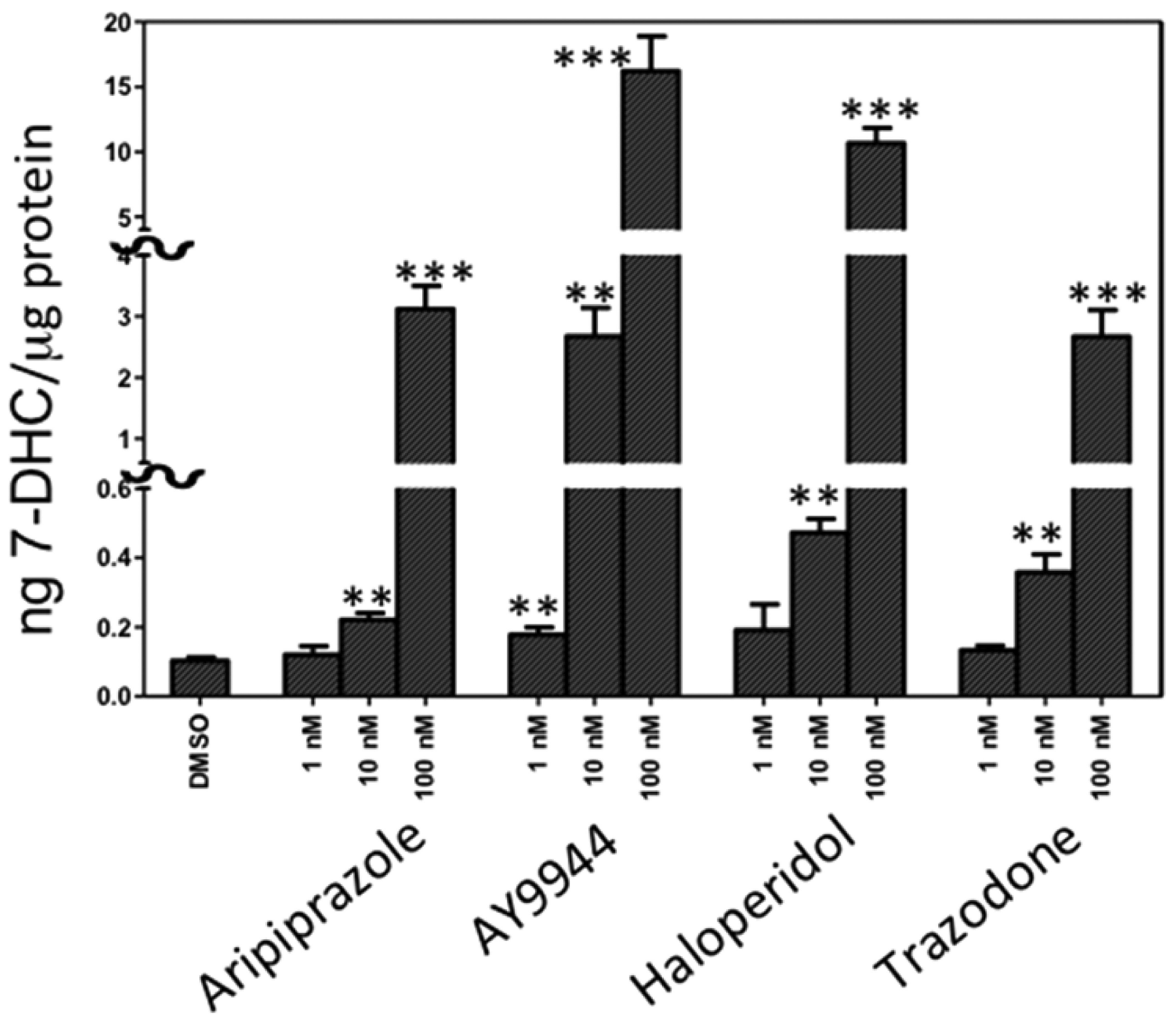

Figure 4.

PTAD screening of Neuro2a cells (control cells) in 96-well plates. Examples of the effect on 7-DHC of some common pharmaceuticals at 1, 10, and $100 \mathrm{nM}$ in cultured control Neuro2a cells. AY9944 is used in a rat SLOS pharmacological model, aripiprazole, haloperidol, and trazodone are widely used atypical antipsychotics and antidepressants. $n>3$; ** $p<0.001$, $* * * p<0.0001$. 


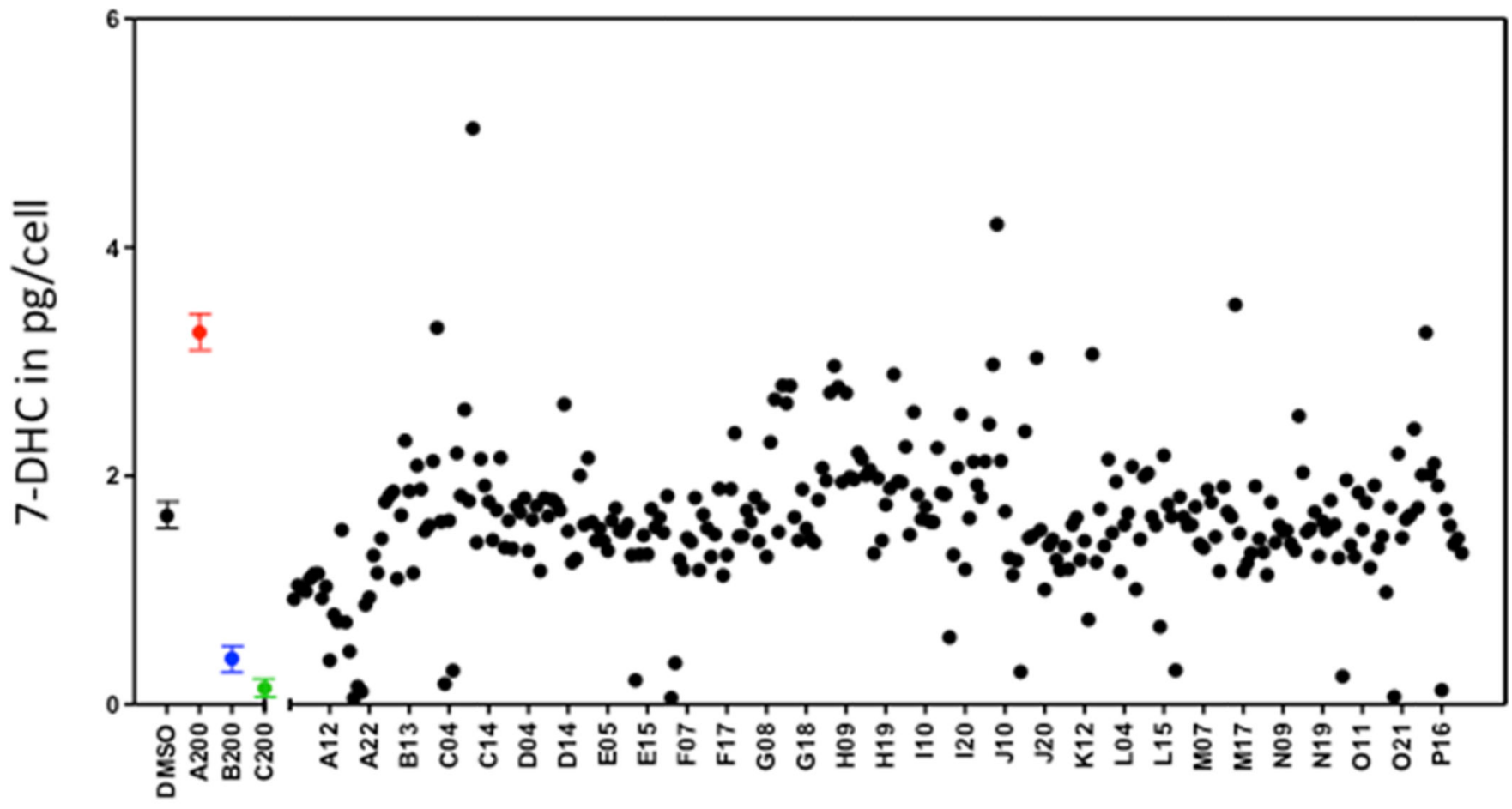

\section{Well Position}

Figure 5.

HTS screening. 7-DHC (pg/cell) in a 384-well plate of Dhcr7-deficient Neuro2a cells plated (13000 cells/well) on 281 of the 727 compounds in the NIH Clinical Collection. First, $1 \mu \mathrm{M}$ of a compound was predeposited in each well and then cells were incubated for $24 \mathrm{~h}$ at $37^{\circ} \mathrm{C}$. 7-DHC levels expressed as pg/number of cells. The left four entries are for DMSO controls $(n=19)$ aripiprazole, bazedoxifene, and clomiphene at $200 \mathrm{nM}$, also shown colorcoded with $n>3 ; * * * p<0.0001$. 

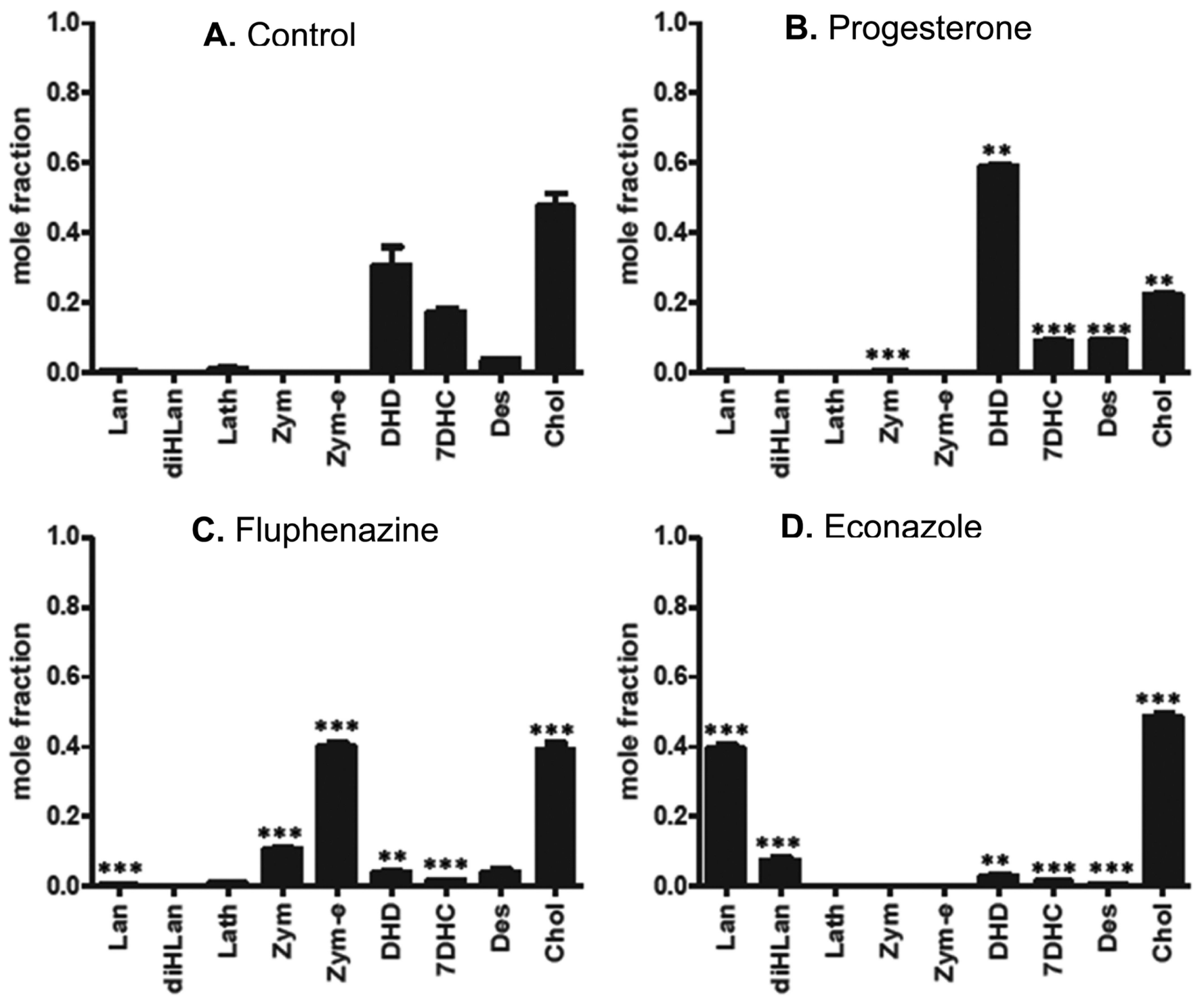

Figure 6.

Sterol profiles for Dhcr7-deficient Neuro2a cells treated with $1 \mu \mathrm{M}$ representative compounds. Mole fraction of the major postlanosterol sterols detected by LC-MS and GCMS. (A) DMSO control, (B) progesterone inhibits DHCR24 and leads to increases in desmosterol (Des) and dehydrodesmosterol (DHD), (C) fluphenazine inhibits EBP ( $\Delta 8-7$ isomerase) and leads to increases in zymosterol (Zym) and zymostenol (Zym-e), (D) econazole inhibits CYP51A1 demethylase and leads to increases in lanosterol (Lan) and dihydrolanosterol (diHLan). Statins (data not shown) inhibit HMGCoA reductase, resulting in a decrease of all sterol intermediates. 

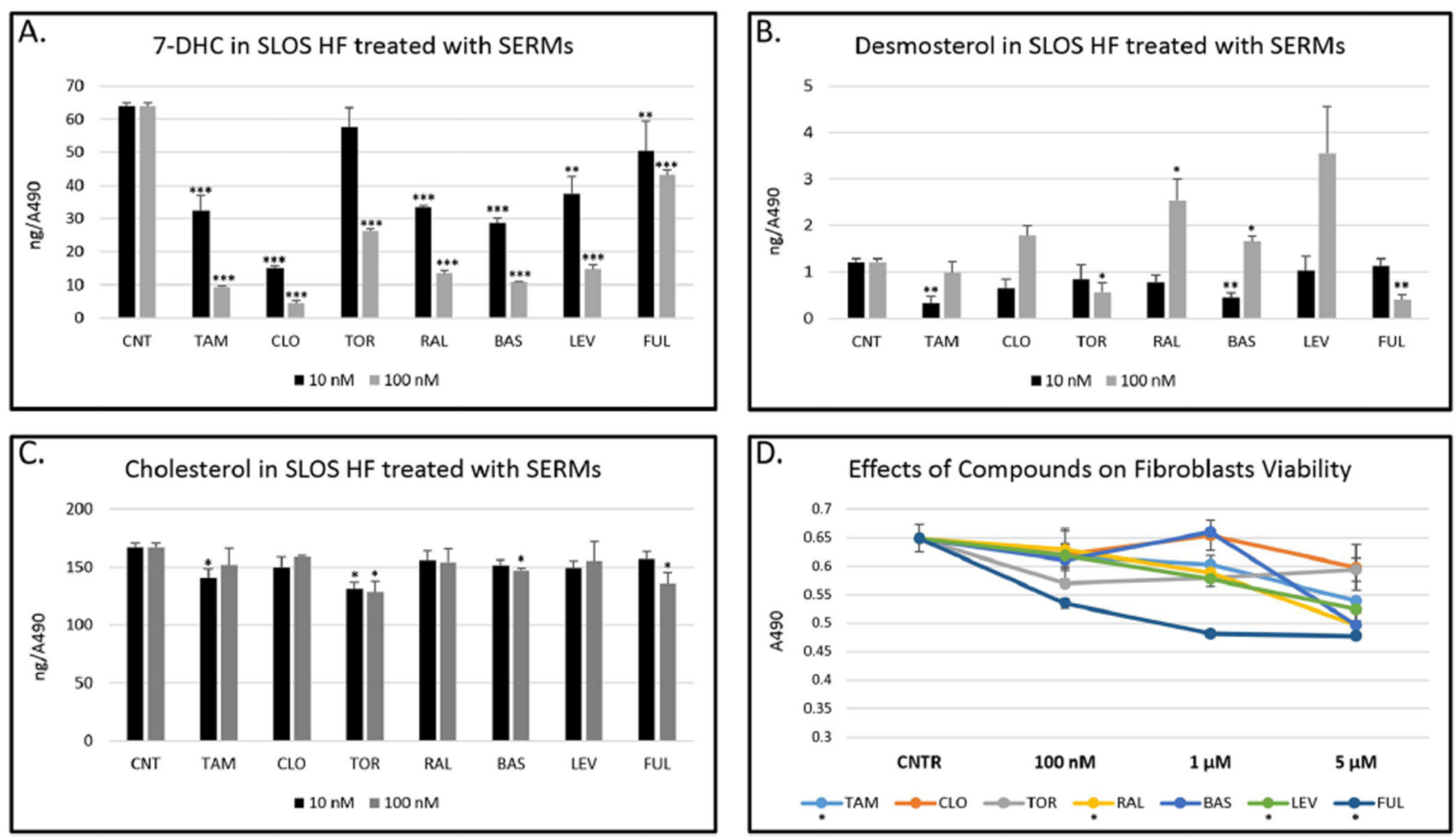

Figure 7.

SERMs alter cholesterol metabolism in SLOS human fibroblasts. SLOS HF were grown in 96-well plates in delipidated serum in the presence of different SERMs for 5 days. The cell viability was assessed by Cell Titer, and the sterol measurements were normalized to the absorbance readings. All SERMs (100 nM) decrease 7DHC (A) with variable effects on desmosterol (B) and cholesterol (C). Different SERMs have variable effects on fibroblasts viability with fulvestrant being the most toxic (D). At $5 \mu \mathrm{M}$, clomiphene is the only SERM without an effect on viability. TAM = tamoxifen, $\mathrm{CLO}=$ clomiphene, $\mathrm{TOR}=$ toremifene, $\mathrm{RAL}=$ raloxifene, $\mathrm{BAS}=$ basedoxifene, $\mathrm{LEV}=$ levormeloxifene, $\mathrm{FUL}=$ fulvestrant . 

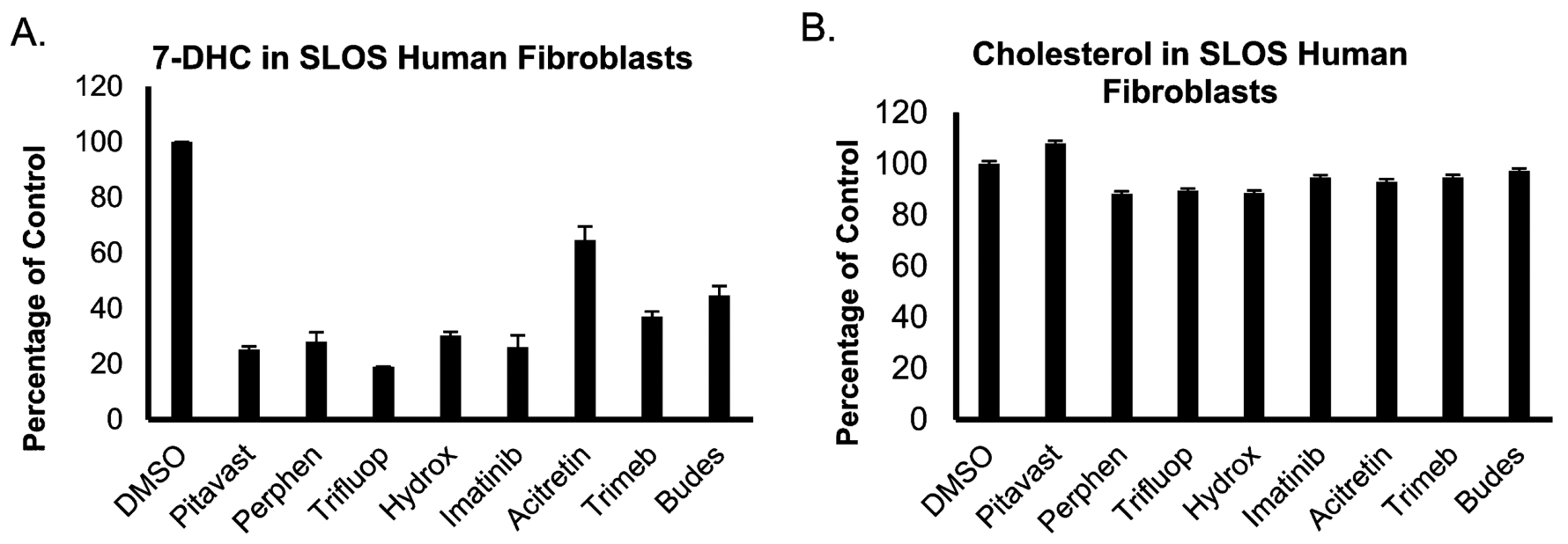

Figure 8.

Selection of small molecules that decrease 7-DHC in SLOS human fibroblasts. SLOS HF were grown in 96-well plates in delipidated serum in the presence of different compounds for 5 days in three different SLOS fibroblasts. All of these compounds (100 nM) decrease 7DHC (A) with only small effects on cholesterol (B). Pitavast = pitavastatin, Perphen = perphazine, Trifluop $=$ Trifluoperphanazine, Hydrox $=$ hydroxyzine, Trime $b=$ trimebutine, Budes $=$ budesonide. 


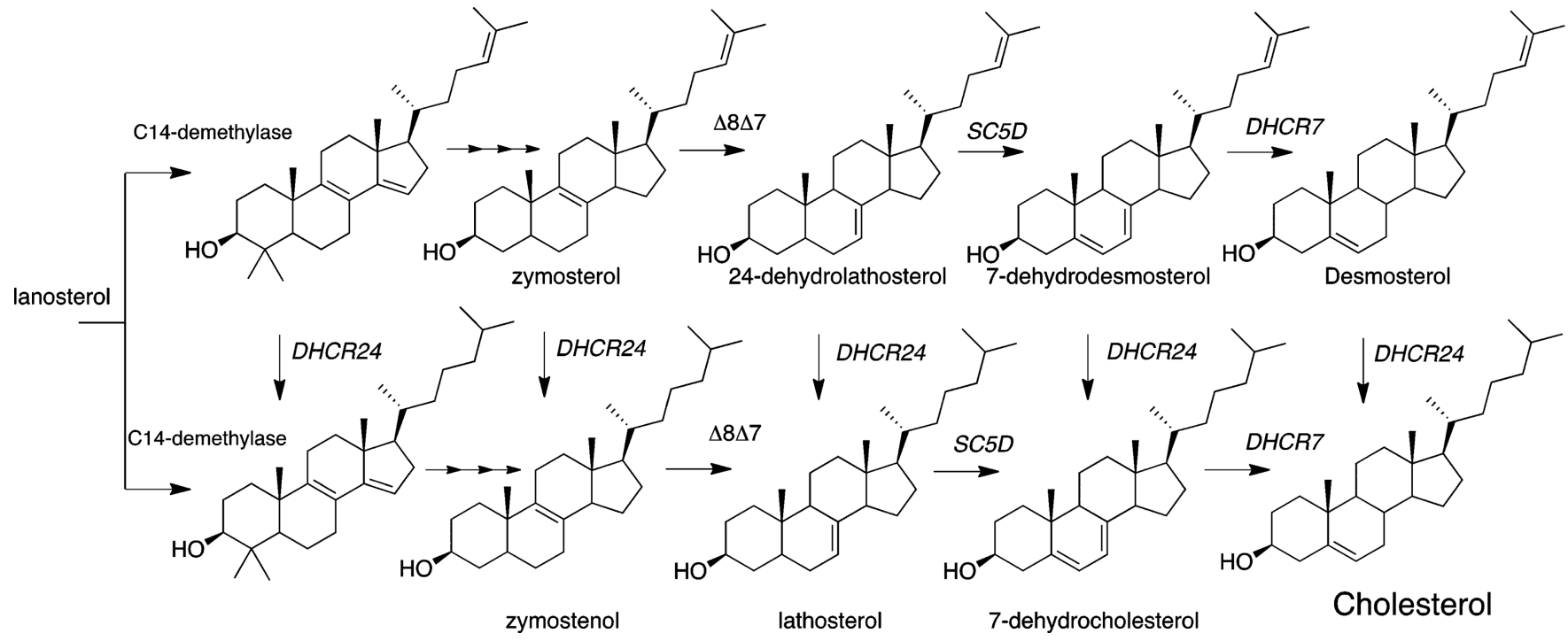

Figure 9.

Selected transformations of postlanosterol cholesterol biosynthesis. 
HMGCoA

Simvastatin

Lovastatin

Mevastatin

Pravastatin

Pitavastatin

Artemether

Artemisinin
$\Delta 8-7$ isomerase

E-clomiphene

Z-clomiphene

Fluphenazine

hydroxyzine

\section{DHCR7 (Chol increase)}

CYP51A1

Chloroxine

Hexachlorophene

homoharringtonine

DHCR24

Trifluoperazine

Tamoxifen

Clomiphene

Toremifene

Raloxifene

Bazedoxifene

Lasofoxifene

Levormeloxifene

Perphenazine

triparanol
Doxepin

prochlorperazine

Molindone

Imatinib

Acitretin

Trimebutine

Moxifloxacin

Fulvestrant

ChemBL327745

Progesterone

Figure 10.

Summary of compounds and sterol transformations affected. 
Table 1

롤

Compounds at $1 \mu \mathrm{M}$ that Decrease 7-DHC in Dhcr7-Deficient Neuro2a Cells ${ }^{g}$

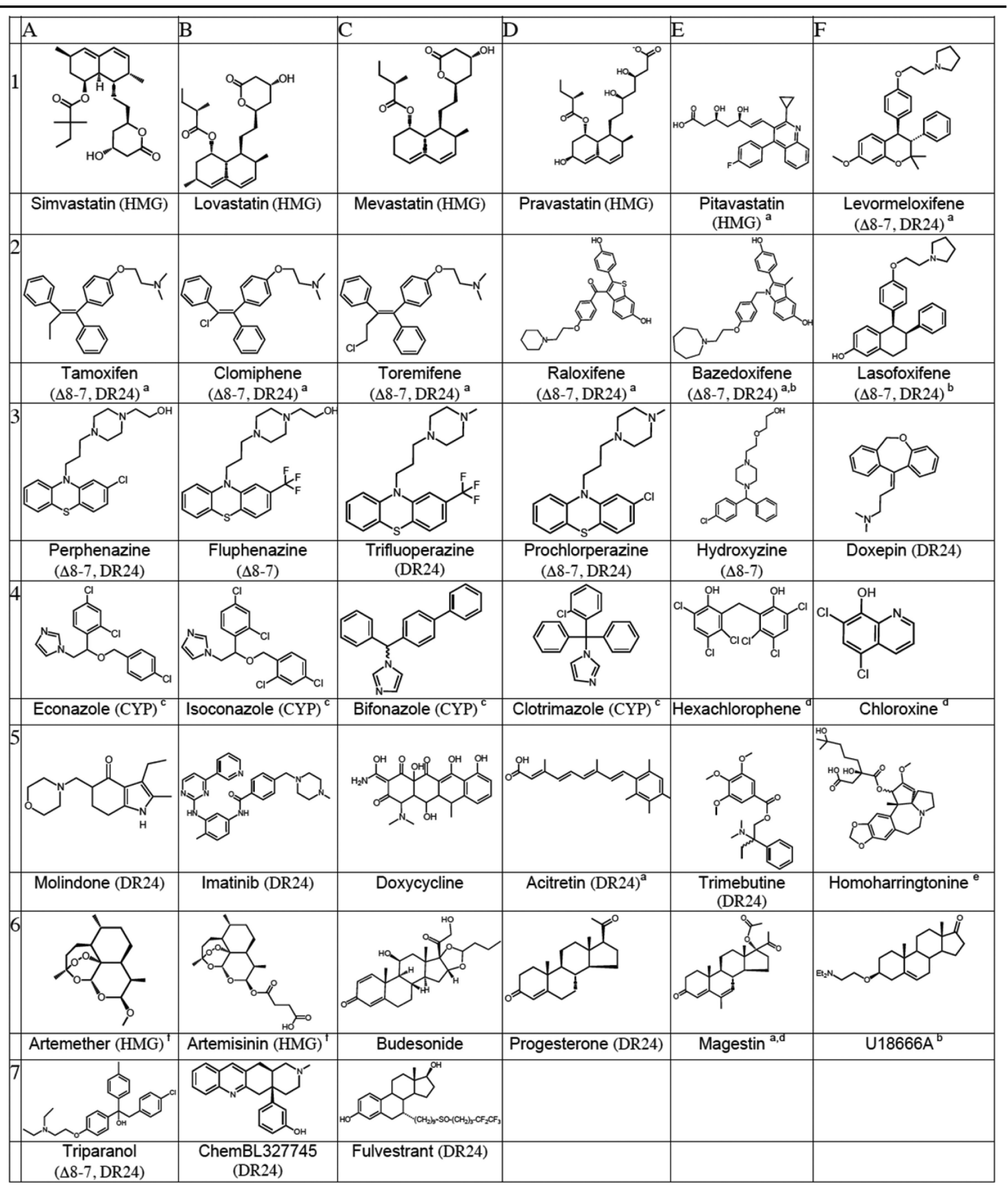

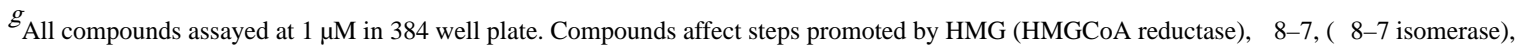
DR24 (DHCR24 reductase) or CYP51 (CYP).

${ }^{a}$ Activity confirmed in human fibroblasts (control or SLOS).

JMed Chem. Author manuscript; available in PMC 2016 April 21. 
${ }^{b}$ Compound not in NIH Clinical Collection.

${ }^{c}$ See ref 59 .

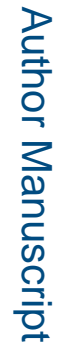

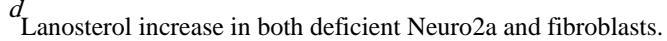

$e^{e}$ Decrease of all sterol intermediates.

$f_{\text {See ref } 60 .}$ 
Table 2

Action, Indication, and FDA Pregnancy Designation for Drugs That Decrease 7-DHC in Dhcr7-deficient Neuro2a ${ }^{a}$

\begin{tabular}{|c|c|c|c|}
\hline name & action & indication & $\begin{array}{c}\text { FDA } \\
\text { category }\end{array}$ \\
\hline simvastatin & statin, HMGCR inhibitor & hyperlipidemia & $\mathrm{X}$ \\
\hline lovastatin & statin, HMGCR inhibitor & hyperlipidemia & $\mathrm{X}$ \\
\hline mevastatin & statin, HMGCR inhibitor & hyperlipidemia & $\mathrm{X}$ \\
\hline pravastatin & statin, HMGCR inhibitor & hyperlipidemia & $\mathrm{X}$ \\
\hline pitavastatin & statin, HMGCR inhibitor & hyperlipidemia & $\mathrm{X}$ \\
\hline tamoxifen & selective estrogen receptor modulator & hormone-receptor-cancer treatment & $\mathrm{D}$ \\
\hline clomiphene & selective estrogen receptor modulator & ovulation induction & $\mathrm{X}$ \\
\hline toremifene & selective estrogen receptor modulator & hormone-receptor-cancer treatment & $\mathrm{D}$ \\
\hline raloxifene & selective estrogen receptor modulator & breast cancer and osteoporosis & $\mathrm{X}$ \\
\hline bazedoxifene & selective estrogen receptor modulator & postmenopausal osteoporosis & $\mathrm{X}$ \\
\hline lasofoxifene & selective estrogen receptor modulator & breast cancer and osteoporosis & $\mathrm{N}$ \\
\hline perphenazine & typical antipsychotic, D1/D2 antagonist & positive symptoms of schizophrenia & $\mathrm{N}$ \\
\hline fluphenazine & typical antipsychotic, D1/D2 antagonist & positive symptoms of schizophrenia & $\mathrm{N}$ \\
\hline trifluoperazine & typical antipsychotic, D1/D2 antagonist & positive symptoms of schizophrenia & $\mathrm{N}$ \\
\hline prochlorperazine & typical antipsychotic, D2 antagonist & antiemetic, antipsychotic, antivertiginoic & $\mathrm{N}$ \\
\hline doxepin & tricyclic antidepressant, SNRI class & depression, anxiety disorders & $\mathrm{N}$ \\
\hline molindone & atypical antipsychotic, D2, 5HT1A-2A, M1 & psychoses and conduct disorder & $\mathrm{N}$ \\
\hline hydroxyzine & antihistaminic, anxiolytic & sedative, allergy, treat hives, runny nose & $\mathrm{C}$ \\
\hline econazole & antimycotic, 14-a demethylase inhibitor & dermatomycoses & $\mathrm{C}$ \\
\hline isoconazole & antimycotic, 14-a demethylase inhibitor & treatment of foot and vaginal infections & $\mathrm{N}$ \\
\hline bifonazole & antimycotic, 14-a demethylase inhibitor & topical fungal infections & 75 \\
\hline clotrimazole & antimycotic, 14-a demethylase inhibitor & topical fungal infections & $\mathrm{C}$ \\
\hline chloroxine & antibacterial, not well understood & dandruff and seborrheic dermatitis & $\mathrm{C}$ \\
\hline hexachlorophene & organochlorine & disinfectant, topical antibacterial & $\mathrm{C}$ \\
\hline artemether & antimalarial, ferriprotoporphyrin IX & malaria treatment & $\mathrm{C}$ \\
\hline artemisinin & antimalarial, ferriprotoporphyrin IX & malaria treatment & $\mathrm{C}$ \\
\hline doxycycline & tetracycline & broad-spectrum antibiotic & $\mathrm{D}$ \\
\hline trimebutine & spasmolytic antimuscarinic and $\mu$-opioid agonist & irritable bowel syndrome & $C^{76}$ \\
\hline homoharringtonine & $\begin{array}{l}\text { cephalotaxine, protein synthesis inhibitor tyrosine } \\
\text { kinase inhibitor }\end{array}$ & hematological malignancies & $\mathrm{D}$ \\
\hline imatinib & tyrosine-kinase inhibitor & $\begin{array}{l}\text { hematological malignancies treatment of multiple } \\
\text { cancers }\end{array}$ & $\mathrm{D}$ \\
\hline budesonide & glucocorticoid & asthma, skin disorders, rhinitis, colitis & $\mathrm{C}$ \\
\hline magestin & progestational hormone & reproductive cancer, anorexia & $\mathrm{X}$ \\
\hline progesterone & progestational steroid & hormone replacement & $\mathrm{B}$ \\
\hline acitretin & retinoid, RXR and RAR & treatment of psoriasis & $\mathrm{X}$ \\
\hline U18666A & & experimental & $\mathrm{N}$ \\
\hline
\end{tabular}

JMed Chem. Author manuscript; available in PMC 2016 April 21. 
${ }^{a}$ Categories: (A) No risk in controlled human studies. Adequate and well-controlled human studies have failed to demonstrate a risk to the fetus in the first trimester of pregnancy (and there is no evidence of risk in later trimesters). (B) No risk in other studies: Animal reproduction studies have failed to demonstrate a risk to the fetus and there are no adequate and well-controlled studies in pregnant women OR Animal studies have shown an adverse effect, but adequate and well-controlled studies in pregnant women have failed to demonstrate a risk to the fetus in any trimester. (C) Risk not ruled out: Animal reproduction studies have shown an adverse effect on the fetus and there are no adequate and well-controlled studies in humans, but potential benefits may warrant use of the drug in pregnant women despite potential risks. (D) Positive evidence of risk: There is positive evidence of human fetal risk based on adverse reaction data from investigational or marketing experience or studies in humans, but potential benefits may warrant use of the drug in pregnant women despite potential risks. (X) Contraindicated in pregnancy: Studies in animals or humans have demonstrated fetal abnormalities and/or there is positive evidence of human fetal risk based on adverse reaction data from investigational or marketing experience, and the risks involved in use of the drug in pregnant women clearly outweigh potential benefits. (N) FDA has not yet classified the drug into a specified pregnancy category. 